Article

\title{
Low Temperature and Cold Stress Significantly Increase Saxitoxins (STXs) and Expression of STX Biosynthesis Genes sxtA4 and sxtG in the Dinoflagellate Alexandrium catenella
}

\author{
Hansol Kim ${ }^{1}$, Hyunjun Park ${ }^{1}$, Hui Wang ${ }^{1}$, Hah Young Yoo ${ }^{1}$, Jaeyeon Park ${ }^{2, *}$ and Jang-Seu Ki ${ }^{1, *}$ (I) \\ 1 Department of Biotechnology, Sangmyung University, Seoul 03016, Korea; 201934001@sangmyung.kr (H.K.); \\ 202032006@sangmyung.kr (H.P.); 201534008@sangmyung.kr (H.W.); y2h2000@smu.ac.kr (H.Y.Y.) \\ 2 Environment and Resource Convergence Center, Advanced Institute of Convergence Technologies, \\ Suwon 16229, Korea \\ * Correspondence: bada0@snu.ac.kr (J.P.); kijs@smu.ac.kr (J.-S.K.); \\ Tel.: +82-31-888-9042 (J.P.); +82-2-2287-5449 (J.-S.K.)
}

check for updates

Citation: Kim, H.; Park, H.; Wang, H.; Yoo, H.Y.; Park, J.; Ki, J.-S. Low Temperature and Cold Stress Significantly Increase Saxitoxins (STXs) and Expression of STX Biosynthesis Genes sxt $A 4$ and $s x t G$ in the Dinoflagellate Alexandrium catenella. Mar. Drugs 2021, 19, 291. https://doi.org/10.3390/md19060291

Academic Editor: Asunción Barbero

Received: 22 April 2021

Accepted: 18 May 2021

Published: 21 May 2021

Publisher's Note: MDPI stays neutral with regard to jurisdictional claims in published maps and institutional affiliations.

Copyright: (c) 2021 by the authors. Licensee MDPI, Basel, Switzerland. This article is an open access article distributed under the terms and conditions of the Creative Commons Attribution (CC BY) license (https:// creativecommons.org/licenses/by/ $4.0 /)$.

\begin{abstract}
Toxic dinoflagellate Alexandrium spp. produce saxitoxins (STXs), whose biosynthesis pathway is affected by temperature. However, the link between the regulation of the relevant genes and STX' accumulation and temperature is insufficiently understood. In the present study, we evaluated the effects of temperature on cellular STXs and the expression of two core STX biosynthesis genes ( $s x t A 4$ and $s x t G$ ) in the toxic dinoflagellate Alexandrium catenella Alex03 isolated from Korean waters. We analyzed the growth rate, toxin profiles, and gene responses in cells exposed to different temperatures, including long-term adaptation $\left(12,16\right.$, and $\left.20^{\circ} \mathrm{C}\right)$ and cold and heat stresses. Temperature significantly affected the growth of $A$. catenella, with optimal growth ( 0.49 division/day) at $16{ }^{\circ} \mathrm{C}$ and the largest cell size $(30.5 \mu \mathrm{m})$ at $12{ }^{\circ} \mathrm{C}$. High concentration of STXs eq were detected in cells cultured at $16^{\circ} \mathrm{C}(86.3 \mathrm{fmol} / \mathrm{cell})$ and exposed to cold stress at $20 \rightarrow 12{ }^{\circ} \mathrm{C}(96.6 \mathrm{fmol} / \mathrm{cell})$ compared to those at $20^{\circ} \mathrm{C}$ and exposed to heat stress. Quantitative real-time PCR (qRT-PCR) revealed significant gene expression changes of $s x t A 4$ in cells cultured at $16^{\circ} \mathrm{C}\left(1.8\right.$-fold) and cold shock at $20 \rightarrow 16{ }^{\circ} \mathrm{C}$ (9.9-fold). In addition, $s x t G$ was significantly induced in cells exposed to cold shocks $\left(20 \rightarrow 16^{\circ} \mathrm{C}\right.$; 19.5 -fold) and heat stress $\left(12 \rightarrow 20^{\circ} \mathrm{C} ; 25.6\right.$-fold). Principal component analysis (PCA) revealed that low temperature $\left(12\right.$ and $\left.16^{\circ} \mathrm{C}\right)$ and cold stress were positively related with STXs' production and gene expression levels. These results suggest that temperature may affect the toxicity and regulation of STX biosynthesis genes in dinoflagellates.
\end{abstract}

Keywords: Alexandrium catenella; saxitoxins (STXs); saxitoxin biosynthesis genes; temperature; transcriptional response

\section{Introduction}

Dinoflagellates are unicellular micro-eukaryotes that mostly inhabit marine water, with some observed in freshwater. They have evolved to adapt to different environments with a variety of morphological diversity and trophic modes [1]. Approximately half of the dinoflagellates are photosynthetic; thus, as a primary producer, they play an important role in aquatic ecosystems [2]. Some dinoflagellates, however, are responsible for harmful algal blooms (HABs), causing considerable damages to marine environments and aquaculture, and even human health [3-5].

In addition, certain dinoflagellates (e.g., Alexandrium catenella, Gymnodinium catenatum, Karenia brevis, and Prorocentrum minimum) can produce biotoxins, such as neurotoxins and hepatotoxins, and these compounds can be accumulated in shellfish via filter feeding [6-8]. Thus, toxic dinoflagellates can cause shellfish poisoning when humans consume contaminated shellfish. Approximately 2000 cases of shellfish poisoning are reported annually around the world, resulting in serious illness or even death [9]. There are four typical 
types of shellfish poisonings, viz., amnesic shellfish poisoning (ASP), diarrhetic shellfish poisoning (DSP), neurotoxic shellfish poisoning (NSP), and paralytic shellfish poisoning (PSP). Among these, PSP is the most serious syndrome reported worldwide, presenting both gastrointestinal and neurological symptoms [10].

Saxitoxin (STX) and its analogues (STXs) are neurotoxins that are naturally produced by certain species of marine and freshwater phytoplankton. STX analogues such as gonyautoxins (GTX1-6), N-sulfocarbamoylgonyautoxins (C1-2), decarbamoylgonyautoxins (dcGTX1-4), STX, neosaxitoxin (neoSTX) and decarbamoylsaxitoxin (dcSTX) are referred to as paralytic shellfish toxins (PSTs). These substances reversibly bind the voltage-gated $\mathrm{Na}+$ channels of neurons, causing paralysis [11,12] and are 2000-times more toxic than sodium cyanide [13]. STX $\mathrm{s}^{\prime}$ accumulation in bivalve filter feeders is well-known and was first described in clam and mussel tissues in 1957 [14]. In marine environments, STXs are primarily produced by toxic dinoflagellates including several Alexandrium species, G. catenatum, and Pyrodinium bahamense $[5,15,16]$.

Cell growth and cellular STXs' content in the toxic Alexandrium species vary according to environmental factors, such as temperature, salinity, light intensity, $\mathrm{CO}_{2}$, and nutrients [17-19]. As eutrophication is responsible for HABs, effects of nutrients on STX biosynthesis have been extensively studied in toxic cyanobacteria and marine dinoflagellates until now $[17,20,21]$. In addition, STXs accumulated in shellfish are detected in spring and autumn off the coasts of temperate regions, including western Mediterranean, Chile, New Zealand, and Korea [22-25]. Vandersea et al. [26] pointed out that the abundance of A. catenella and STXs' production may be more related to water temperature than to nutrients or salinity. Although controversial, environmental surveys and laboratory experiments suggest that temperature may affect STX s' $^{\prime}$ production in toxic Alexandrium [27-29]. It is also confusing whether it is due to cellular biomass changes or triggering of STX biosynthesis $[17,19,30]$. Hence, to understand the influence of abiotic factors at the molecular level, research on STX synthesis genes is necessary.

STX biosynthesis gene clusters were first identified in the freshwater cyanobacterium Cylindrospermopsis raciborskii [31], followed by Anabaena circinalis, Aphanizomenon gracile [32] and Dolichospermum circinale [33]. STX biosynthetic pathways have been proposed in cyanobacteria [32]. These studies have identified at least 26 enzymes (e.g., sxtA, sxtG, sxtB, sxtC, sxtD, and sxtH/T) involved in the biosynthesis, tailoring, transport, and/or regulation of STXs. These findings suggested that toxic dinoflagellates seem to harbor a similar system for STX biosynthesis. Thus, considering STX biosynthesis genes in toxic cyanobacteria, many researchers have explored their homologs and orthologs in marine dinoflagellates using gene cloning, transcriptomics, and synthetic pathway analysis $[3,34,35]$. In contrast to cyanobacteria, molecular studies on STX-producing dinoflagellates are limited and are further complicated owing to their extraordinary genetic characteristics, including a huge genome, permanently condensed chromosomes, high GC content, and post-transcriptional regulation [36]. Recent large-scale transcriptomic analyses using next-generation sequencing (NGS) have enabled the characterization and identification of homologous genes in toxic Alexandrium [37-43].

STX biosynthesis begins with a polyketide-like synthase, catalyzing arginine and malonyl-CoA; this is followed by another reaction catalyzed by amidinotransferase that transfers the amidino group from arginine [44]. sxtA enzyme comprises four catalytic domains, and the enzyme serves as S-adenosyl-methionine (SAM)-dependent methyltransferase (sxtA1), GCN5-related N-acetyltransferase (sxtA2), acyl carrier protein (sxtA3), and a class II aminotransferase (sxtA4). Particularly, sxtA4 is important for STX biosynthesis because it is not present in non-toxic dinoflagellates [31,40,41,45,46]. In addition, our recent transcriptomic analysis showed that the toxic Alexandrium spp. contain most of the core STX biosynthesis genes $(s x t A, s x t B, s x t D, s x t G, s x t H / T, s x t I, s x t S$, and $s x t U)$, whereas their structural modifications and/or absence were observed in non-toxic dinoflagellates [41,42]. Of these genes, sxt $A$ and $s x t G$ are involved in the initial steps of STX biosynthesis and have been investigated at transcriptomic and genomic levels [45,47]. To date, these genes 
are considered to play the most important role in STX biosynthesis [48]; however, the relationship between STX toxicity and response of the core genes to environmental factors is insufficiently understood.

In the present study, we evaluated the effects of temperature on cellular STX' ${ }^{\prime}$ accumulation and expression of the two core STX biosynthesis genes, sxtA4 and sxt $G$, in the toxic dinoflagellate Alexandrium catenella (Alex03). Then, we compared the relationship between temperature and STX production through transcriptional regulation. The test species occurs predominantly in Korean coasts and is suspected to cause PSP in marine aquaculture thorough molecular phylogeny and laboratory culture researches $[49,50]$.

\section{Results}

\subsection{Effects of Temperature on Cell Growth and Size}

Alexandrium catenella Alex 03 was cultured at $20^{\circ} \mathrm{C}$, and was successively adapted to different temperatures $\left(16{ }^{\circ} \mathrm{C}\right.$ and $\left.12{ }^{\circ} \mathrm{C}\right)$. Cells cultured at lower temperatures were healthy and not much different compared to those cultured at $20^{\circ} \mathrm{C}$. Cell growth patterns in the three test temperatures showed sigmoidal cell growth at $16{ }^{\circ} \mathrm{C}$ but relatively slow growth at $12{ }^{\circ} \mathrm{C}$ and $20^{\circ} \mathrm{C}$ (Figure 1A). Comparisons at the exponential phase (day 18) revealed that cell number at $16^{\circ} \mathrm{C}$ was much higher than that at $12{ }^{\circ} \mathrm{C}\left(2.9\right.$-times at $\left.16^{\circ} \mathrm{C}\right)$ and $20^{\circ} \mathrm{C}$ (4.7-times at $\left.16^{\circ} \mathrm{C}\right)$. Hence, optimal cell growth was recorded at $16^{\circ} \mathrm{C}$, with the maximum cell density of $5.9 \times 10^{3}$ cells $/ \mathrm{mL}$, of which growth rate was calculated to be 0.49 division/day.

A

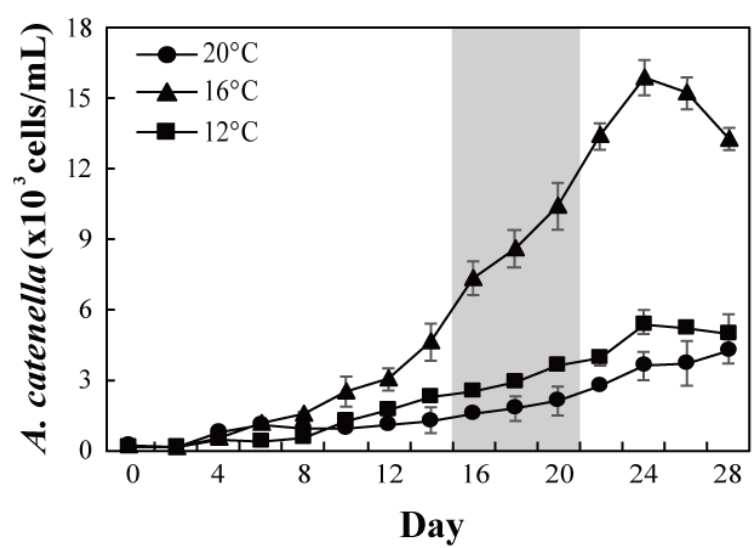

B

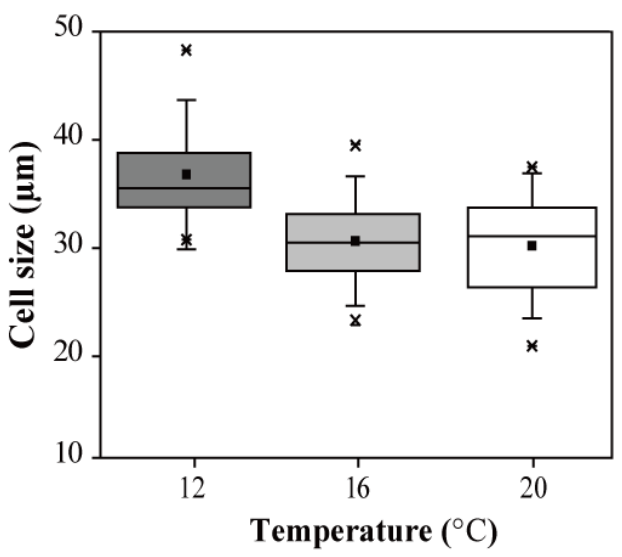

C

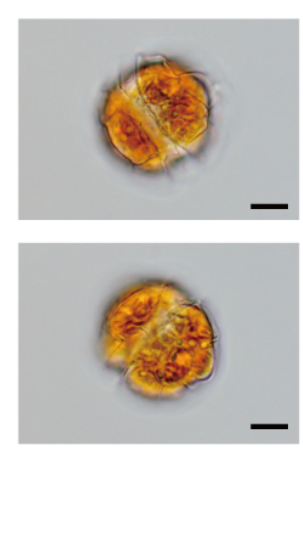

Figure 1. Growth curves (A) and box plots of cell size (B) of Alexandrium catenella Alex03 dependent on adapted temperature $\left(12,16\right.$, and $\left.20^{\circ} \mathrm{C}\right)$. The "** were determined by the 1st and 99th percentiles. Morphology of $A$. catenella observed in brightfield microscopy (scale bar: $20 \mu \mathrm{m}$ ) (C). Cell growth was observed over a period of 28 days, and the gray background in growth curve represents the presence of an exponential phase. The size of the cells harvested on day 18, i.e., the exponential phase was analyzed.

The average cell size of three cultures was the largest at $12^{\circ} \mathrm{C}(36.7 \pm 0.5 \mu \mathrm{m})$, followed by those at $16^{\circ} \mathrm{C}(30.7 \pm 0.3 \mu \mathrm{m})$ and $20^{\circ} \mathrm{C}(30.5 \pm 0.5 \mu \mathrm{m})$ (Figure 1B). The widest distribution of cell size was recorded at $20^{\circ} \mathrm{C}$, ranging from 23.1 to $37.4 \mu \mathrm{m}$.

\subsection{Phylogenetic Relationships of sxt $A 4$ and sxt $G$ and Characterization}

Partial open reading frame (ORF) sequences of $s x t A 4$ and $s x t G$ from $A$. catenella were determined to be $714 \mathrm{bp}$ and $1112 \mathrm{bp}$, respectively. BLASTx search of the sxtA4 sequence of Alex03 (GenBank accession no. MW884259) showed 100\% identity with that of the dinoflagellate $A$. fundyense (ADY62525), followed by $99.5 \%$ with A. tamarense (BCG06333) and $96.3 \%$ with $A$. australiense (AIY25738). The sxtG sequence (MW884258) of Alex03 matched $100 \%$ with the same gene of $A$. tamarense (AGC84356), 99.7\% with A. fundyense (AGC84339.1), and 96.3\% with A. insuetum (AGC84351). In silico analyses of functional 
domains predicted that a class II aminotransferase was present at 23 to 226 amino acid residue of $s x t A 4$ protein, whereas no specific domain was found in $s x t G$ of Alex03.

In addition, we investigated phylogenetic relationships of the genes $s x t A 4$ and $s x t G$ using broad taxon samplings from NCBI. ML trees of the deduced amino acid sequences showed that $A$. catenella Alex03 obviously formed one well-supported cluster, with the already known Alexandrium spp. (Figure 2). In particular, the phylogenetic tree of $s x t A 4$ showed that the gene was clustered with $A$. fundyense and $A$. tamarense, and it formed a sister clade, which was separated into cyanobacteria and bacteria. In addition, sxtG protein also clustered into a single clade, which included other Alexandrium species (A. catenella, A. fundyense, A. insuetum) and G. catenatum. The sxtG clade was divided into two sub-clusters of fungi and the sister clades of cyanobacteria and metazoa.

A

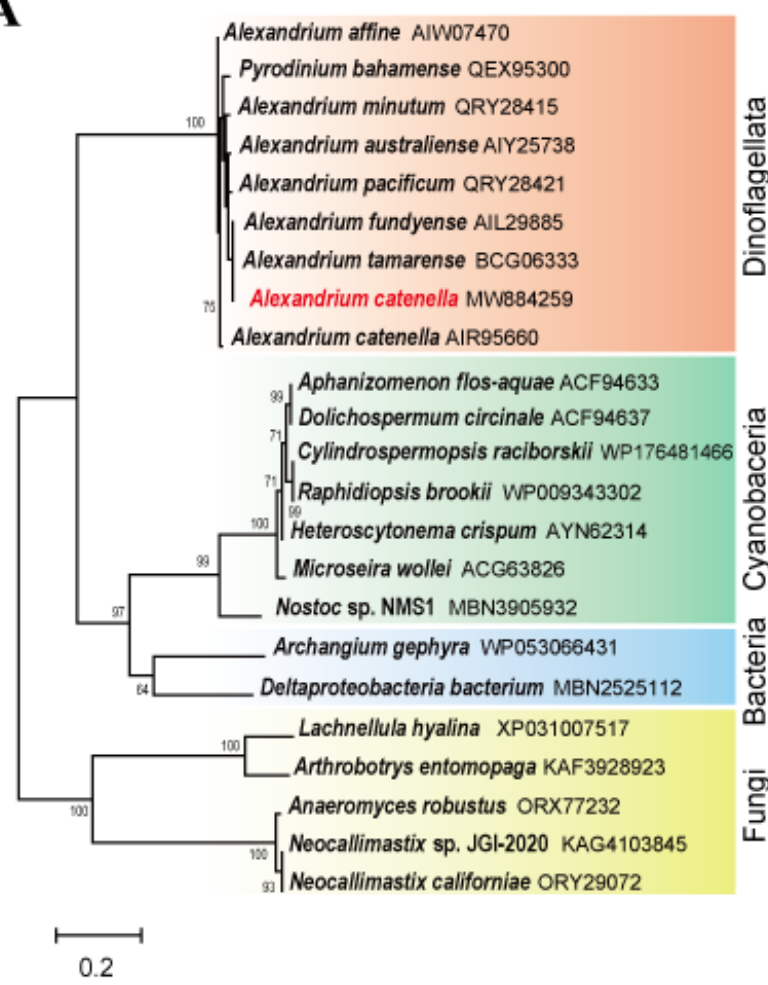

B

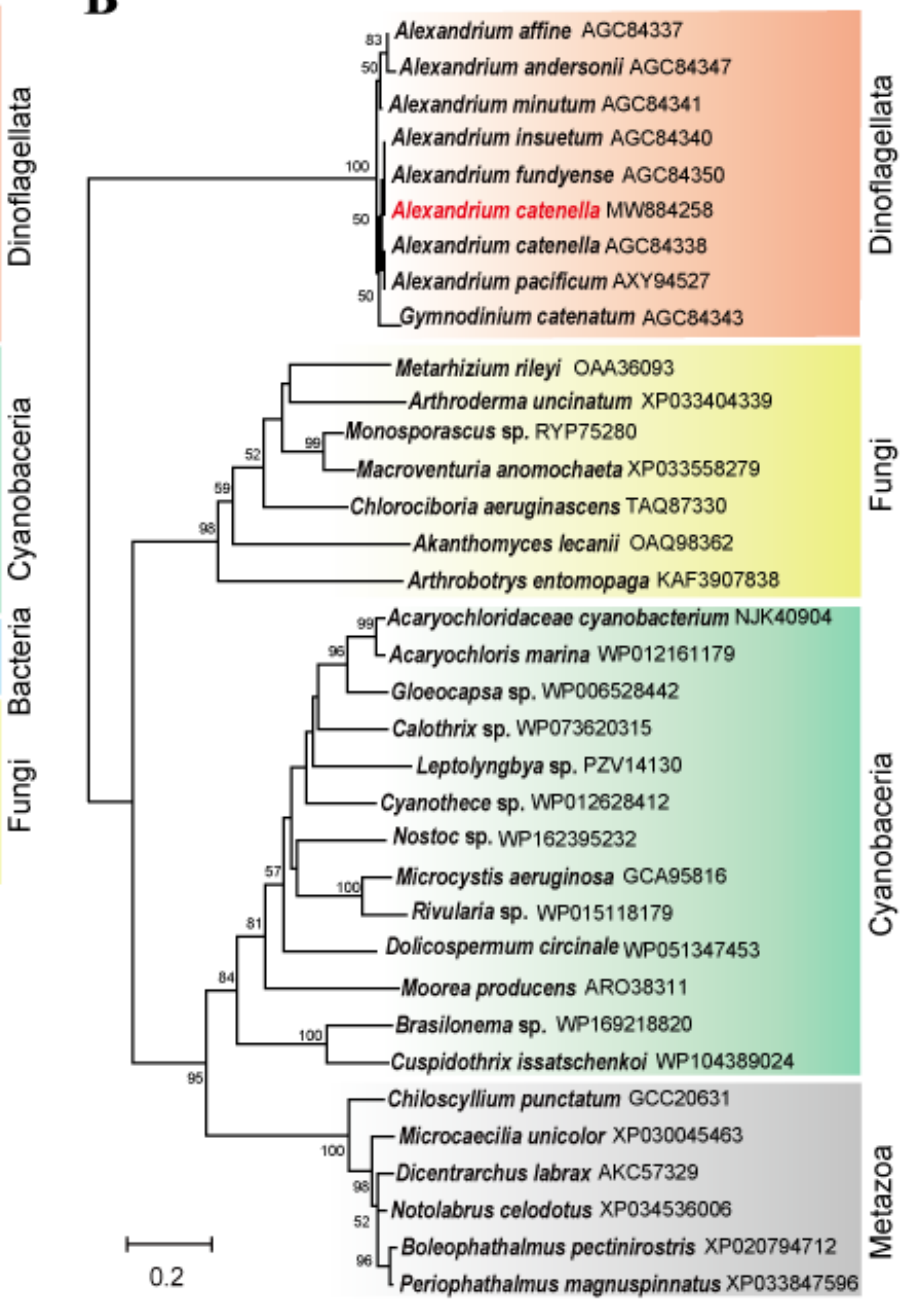

Figure 2. Phylogenic trees of $\operatorname{sxt} A 4(\mathbf{A})$ and $\operatorname{sxt} G(\mathbf{B})$. The tree was separately constructed with deduced amino acid sequences of sxtA4 and sxtG using maximum likelihood (ML) method. The sequences of Alexandrium catenella Alex03 are marked in red. GenBank accession numbers are given after species name.

\subsection{Effect of Water Temperature on STXs}

Total STXs eq for each sample was determined by summing 12 STX analogues calculated with toxicity equivalency factors (TEF). The results showed that temperature significantly changed the total STXs eq and their profiles in A. catenella (Figure 3). STXs eq was the highest at $16^{\circ} \mathrm{C}(86.38 \mathrm{fmol} / \mathrm{cell})$, which was 3.6- and 1.2-times higher than that at $20{ }^{\circ} \mathrm{C}(p<0.001)$ and $12{ }^{\circ} \mathrm{C}(p<0.01)$, respectively. In addition, total STXs eq 
increased significantly when exposed to $20 \rightarrow 12{ }^{\circ} \mathrm{C}(96.67 \mathrm{fmol} /$ cell; $p<0.001)$, followed by $20 \rightarrow 16^{\circ} \mathrm{C}$ ( $\left.59.15 \mathrm{fmol} / \mathrm{cell} ; p<0.01\right)$ and $16 \rightarrow 12{ }^{\circ} \mathrm{C}$ (30.07 fmol/cell; $\left.p<0.05\right)$. Interestingly, there was no significant changes in STXs eq of heat stress samples, including $16 \rightarrow 20^{\circ} \mathrm{C}$ (33.06 fmol/cell), $12 \rightarrow 20{ }^{\circ} \mathrm{C}$ ( $31.38 \mathrm{fmol} /$ cell), and $12 \rightarrow 16^{\circ} \mathrm{C}$ (14.68 fmol/cell) compared to that of $20^{\circ} \mathrm{C}$.
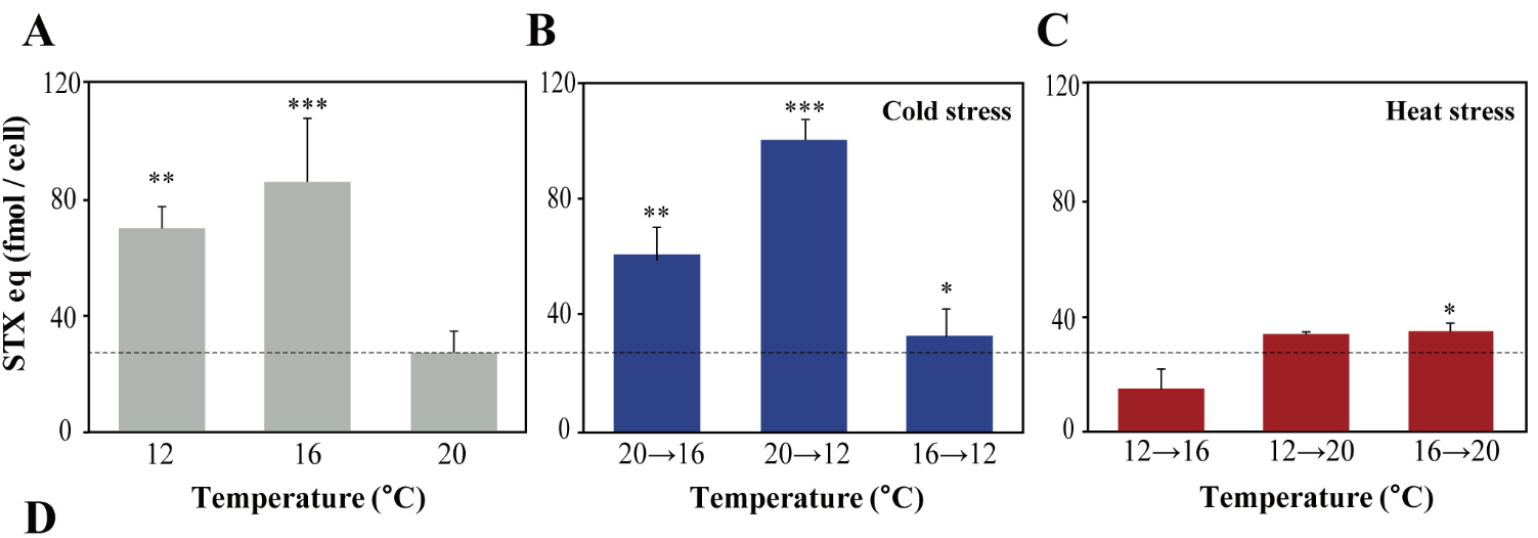

\begin{tabular}{|c|c|c|c|c|c|c|c|c|c|c|c|c|c|c|}
\hline \multirow{3}{*}{\multicolumn{2}{|c|}{$\begin{array}{c}\text { Toxicity level } \\
\text { Culture condition }\end{array}$}} & \multicolumn{10}{|c|}{ High } & \multicolumn{3}{|c|}{ Low } \\
\hline & & \multicolumn{13}{|c|}{ Concentration of saxitoxins equivalent (fmol/cell) } \\
\hline & & STX & GTX 1 & neoSTX & GTX 4 & GTX 3 & dcGTX 3 & deSTX & GTX 2 & dcGTX 2 & $\mathrm{C} 2$ & $\mathrm{C} 1$ & GTX 6 & Total \\
\hline \multirow{3}{*}{ Adaptation } & $12^{\circ} \mathrm{C}$ & 0.02 & 31.64 & - & 21.66 & 11.90 & - & - & - & - & 0.62 & 1.58 & - & 67.42 \\
\hline & $16^{\circ} \mathrm{C}$ & 0.00 & 75.35 & - & - & 8.84 & - & - & - & - & 0.80 & 1.37 & - & 86.38 \\
\hline & $20^{\circ} \mathrm{C}$ & 0.03 & 14.68 & - & - & 8.39 & - & - & - & - & 0.47 & 0.27 & - & 23.84 \\
\hline \multirow{3}{*}{ Cold stress } & $20 \rightarrow 16^{\circ} \mathrm{C}$ & - & 30.25 & - & 17.85 & 10.22 & - & - & - & - & 0.80 & 0.03 & - & 59.15 \\
\hline & $20 \rightarrow 12^{\circ} \mathrm{C}$ & - & 59.75 & - & 16.16 & 15.59 & - & - & - & 4.04 & 1.13 & - & - & 96.67 \\
\hline & $16 \rightarrow 12^{\circ} \mathrm{C}$ & - & 5.87 & - & 3.78 & 3.03 & 3.68 & 0.00 & 12.62 & 0.48 & 0.61 & - & - & 30.07 \\
\hline \multirow{3}{*}{ Heat stress } & $12 \rightarrow 16^{\circ} \mathrm{C}$ & 0.52 & 3.92 & 0.43 & - & 8.89 & 0.26 & 0.15 & 0.19 & 0.02 & 0.30 & - & 0.00 & 14.68 \\
\hline & $12 \rightarrow 20^{\circ} \mathrm{C}$ & 1.33 & 12.64 & 1.16 & 0.04 & 14.87 & - & 0.29 & 0.29 & 0.09 & 0.67 & 0.00 & 0.00 & 31.38 \\
\hline & $16 \rightarrow 20^{\circ} \mathrm{C}$ & 1.12 & 6.97 & 0.83 & 0.02 & 22.29 & - & 0.45 & 0.29 & 0.06 & 1.03 & 0.00 & - & 33.06 \\
\hline
\end{tabular}

Figure 3. Comparison of saxitoxins equivalent (STXs eq) of Alexandrium catenella Alex03 in different temperatures; adaptation temperature (A), cold stress (B), and heat stress (C). The mean STXs eq (fmol/cell) for each STX analogues and total STXs eq were calculated and displayed to two decimal places. Undetected analogues were marked ' - '. The proportion of each STX analogues (\%) to the total STXs eq is expressed by a heatmap (D). Significant differences between the control and treated samples were determined by one-way ANOVA and highlighted as ${ }^{*} p<0.05,{ }^{* *} p<0.01$, and ${ }^{* *} p<0.001$.

The STX s' $^{\prime}$ profiles of $A$. catenella exposed to different temperatures and cold/heat stress were compared (Figure 3D). Of the 12 STXs, GTX1, GTX3, and GTX4 were most dominantly detected in Alex03. Particularly, GTX1 accounts for the highest proportion of total STXs eq, which is up to $87.2 \%$ at $16{ }^{\circ} \mathrm{C}$ and $61.8 \%$ at $20 \rightarrow 12{ }^{\circ} \mathrm{C}$. GTX4 then constitutes $32.1 \%$ at $12{ }^{\circ} \mathrm{C}$ and $30.1 \%$ at $20 \rightarrow 16{ }^{\circ} \mathrm{C}$. In addition, GTX3 accounted up to $67.4 \%$ at $16 \rightarrow 20^{\circ} \mathrm{C}$. STX, dcSTX, neoSTX, and GTX2 were mainly detected in heat shock samples 
and the others were negligibly found (less than 5\%), except for dcGTX3 (12.2\%) and GTX2 $(41.9 \%)$ in $16 \rightarrow 12{ }^{\circ} \mathrm{C}$.

\subsection{Effects of Different Temperatures on sxtA4 and sxt $G$ Transcription}

The relative expression levels of the genes, $s x t A 4$ and $s x t G$, were evaluated in $A$. catenella Alex03 exposed to different temperatures for $72 \mathrm{~h}$ (Figure 4). The relative expressional levels of each gene were normalized using TUA. Expressional levels of sxtA4 were significantly upregulated at $12{ }^{\circ} \mathrm{C}$ (5.4-fold), $16^{\circ} \mathrm{C}$ (3.7-fold), and cold stresses (9.9-fold changes at $20 \rightarrow 16^{\circ} \mathrm{C}, 5.2$-fold at $16 \rightarrow 12{ }^{\circ} \mathrm{C}$, and 4.5 -fold at $20 \rightarrow 12{ }^{\circ} \mathrm{C}$ ) compared to control $\left(20^{\circ} \mathrm{C}\right)$. Heat stress, however, significantly reduced $s x t A 4$ expression levels $(0.1$-fold change at $12 \rightarrow 16^{\circ} \mathrm{C}$ and 0.08 -fold at $\left.12 \rightarrow 20^{\circ} \mathrm{C} ; p<0.001\right)$. In addition, relative expression levels of $s x t G$ significantly increased when subjected to temperature changes (19.5-, 16.2-, 13.3-, 18.6-, and 25.6-fold at $20 \rightarrow 16{ }^{\circ} \mathrm{C}, 16 \rightarrow 12{ }^{\circ} \mathrm{C}, 20 \rightarrow 12{ }^{\circ} \mathrm{C}, 12 \rightarrow 16^{\circ} \mathrm{C}$, and $12 \rightarrow 20^{\circ} \mathrm{C}$, respectively) compared to control $\left(20^{\circ} \mathrm{C}\right)$.

A

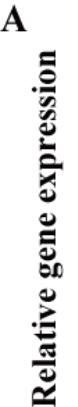

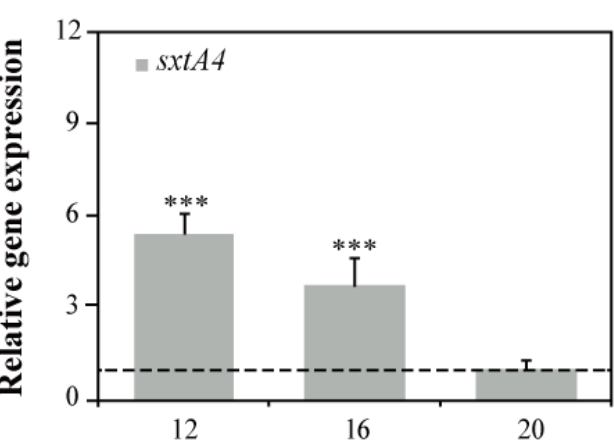

B

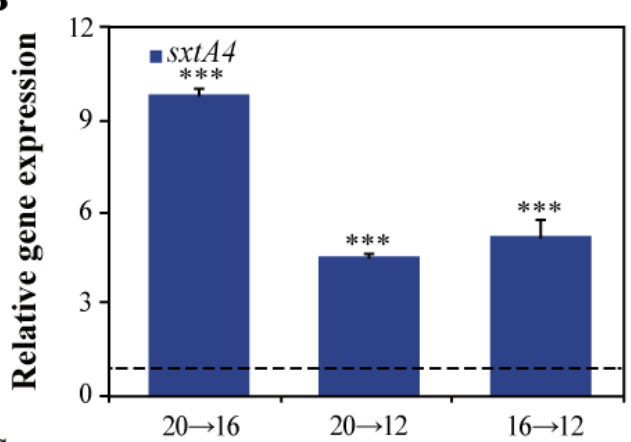

C

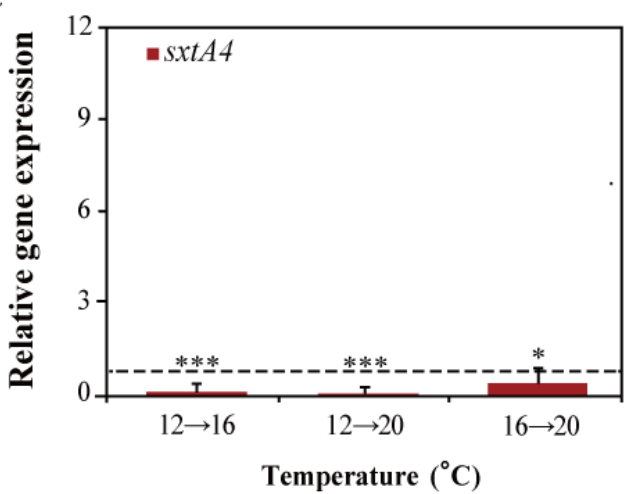

D

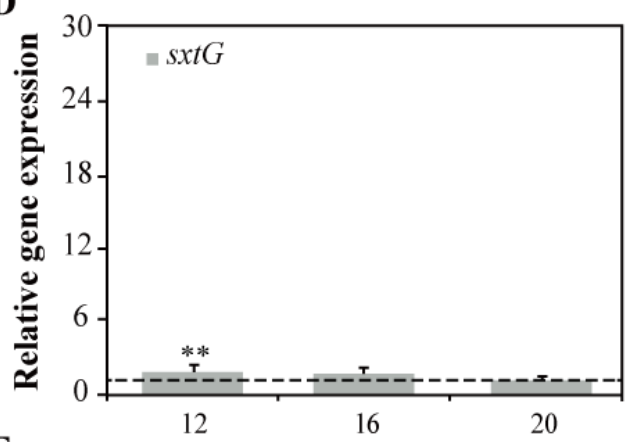

$\mathbf{E}$

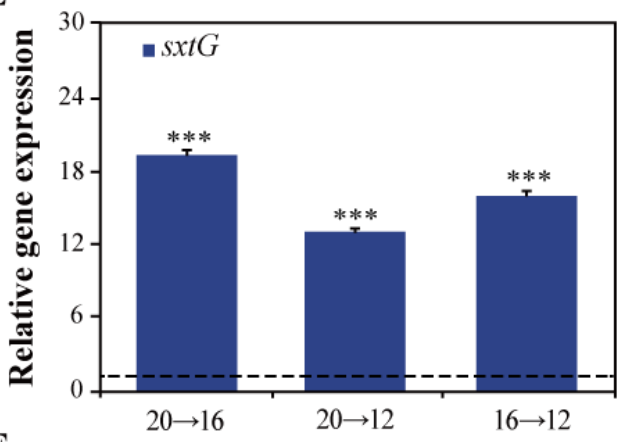

$\mathbf{F}$

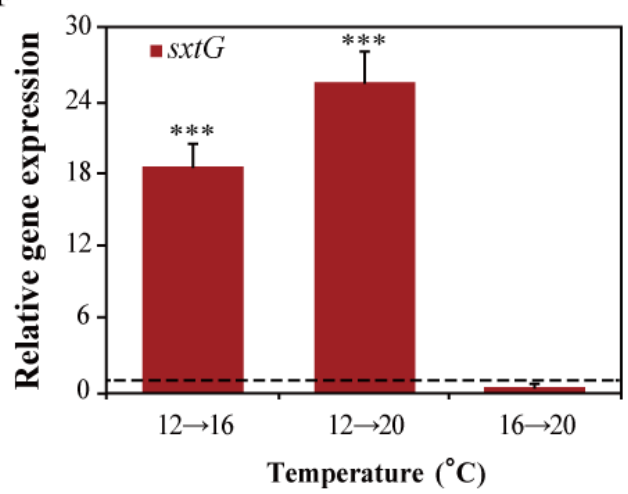

Figure 4. Changes in expression levels of $s x t A 4(\mathbf{A}-\mathbf{C})$ and $s x t G(\mathbf{D}-\mathbf{F})$ dependent on culture conditions with different temperature. $\alpha$-tublin (TUA) was used to normalize between different samples. Significant differences between the control and treated samples were determined by one-way ANOVA and highlighted as ${ }^{*} p<0.05,{ }^{* *} p<0.01$, and ${ }^{* * *} p<0.001$. 


\subsection{Correlation of Temperature, STXs eq and Sxt Genes Expression}

PCA analysis showed a distinct partitioning of heat and cold stress samples and correlation with total STXs eq, sxtA4 and sxtG expression levels (Figure 5). The ordination plot showed $99.19 \%$ of total variation in the data, and a linear positive relation was shown between STXs eq toxicity, sxtA4, and sxtG. PCA1 explained $92.43 \%$ of the variance, whereas PCA2 explained $6.76 \%$ of the variance. The samples cultured at $20{ }^{\circ} \mathrm{C}, 16 \rightarrow 20{ }^{\circ} \mathrm{C}$, and $12 \rightarrow 20^{\circ} \mathrm{C}$ (heat stress) were well-represented on the negative part of PCA1, with no strong relation between STXs eq, $s x t A 4$, and $s x t G$. Conversely, cold stress samples $\left(20 \rightarrow 16^{\circ} \mathrm{C}\right.$, $20 \rightarrow 12{ }^{\circ} \mathrm{C}$ and $16 \rightarrow 12{ }^{\circ} \mathrm{C}$ ) and those cultured at $12{ }^{\circ} \mathrm{C}$ and $16{ }^{\circ} \mathrm{C}$ were clustered in the positive portion of PCA1. Strong affinity was observed between cold stress and STXs eq and expressional levels of the genes.

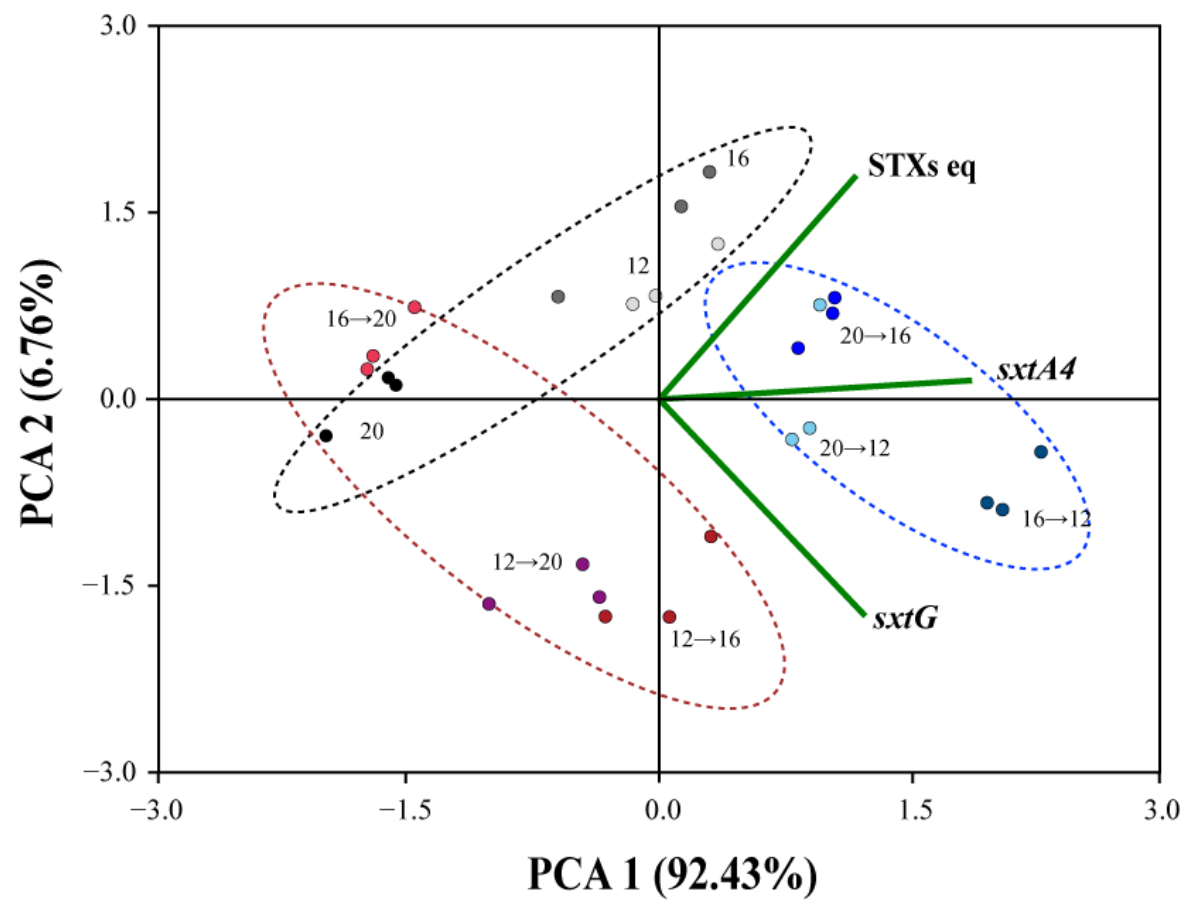

Figure 5. Principal component analysis (PCA) of temperature parameters (adaptation temperature, cold stress, and heat stress) for saxitoxins equivalent (STXs eq) and relative expression levels of STX biosynthesis-related genes ( $s x t A 4$ and $s x t G$ ).

\section{Discussion}

A. catenella is known for producing STXs, but its toxicity varies depending on geographical origin and environmental conditions, even for cultured strains [4,51,52]. A. catenella Alex03 was isolated in 2017 from Jeju Island coasts, Korea. Although it had been cultured for a long time and adapted well to laboratory conditions, we found that the morphology and STX' toxicity may not or were lightly altered. In addition, comparisons of the $28 \mathrm{~S}$ rRNA sequences showed that $A$. catenella Alex03 (GenBank accession no. MW882944) shared 100\% similarity with $A$. catenella CCAP-1119/32 (MK566200; isolated from Scotland), H5 (MK566199; Argentina), and SCCAP K-1490 (MK566199; Canada). These results suggested that Alex03 was genetically similar or identical to $A$. catenella distributed in coastal waters around the world. The present research firstly evaluated STX' production of A. catenella Alex03 isolated from Korean coast and analyzed the regulation of sxt genes under different temperature conditions.

Molecular phylogeny using $28 \mathrm{~S}$ rRNA showed that $A$. catenella Alex03 belonged to Group I (=A. fundyense) of A. tamarense complex [53,54], of which members are known as STX-producing Alexandrium [16,55]. Alex03 produced different levels of STXs in all 
culture conditions. In addition, its STXs eq toxicity (14-96 fmol/cell) was comparable to those reported previously in A. catenella (Table 1). The test strain (Alex03) showed optimal growth at $16^{\circ} \mathrm{C}$, in agreement with previous reports [56-58]. For examples, A. catenella CCAP-1119/27, ATTL01 and ATTL02, and BAH91 contained $2732.5 \mathrm{fg} / \mathrm{cell}, 5-44 \mathrm{fg} / \mathrm{cell}$, and $9.9 \mathrm{fmol} /$ cell when maintained at $15{ }^{\circ} \mathrm{C}$. In addition, A. catenella ACC02 maintained at low temperature $\left(10^{\circ} \mathrm{C}\right)$ were found to be the most toxic $(27.7 \mathrm{fmol} / \mathrm{cells})$ [56]. These results reveal that the high toxicity of $A$. catenella may be related to optimal growth temperature at around $16{ }^{\circ} \mathrm{C}$. Moreover, the difference in STXs' toxicity may be caused by the components of STXs, in which STX and GTX1 were much more toxic than C1 and C2 [59]. A. catenella ACT03 showed different dominant analogues depending on culturing temperatures, for example, $\mathrm{C} 1$ at $12{ }^{\circ} \mathrm{C}$ and GTX4 at $18-30{ }^{\circ} \mathrm{C}$ [58]. These results were well-matched with that of Alex03, in which GTX1 was dominantly analyzed at $16{ }^{\circ} \mathrm{C}$.

Table 1. Toxin production in the genus Alexandrium under different temperatures from published literatures.

\begin{tabular}{|c|c|c|c|c|c|}
\hline Species & Strain & Temperature & Toxins & STXs eq (fmol/cell) & Reference \\
\hline \multirow{6}{*}{ Alexandrium catenella } & ACC02 & $10-16^{\circ} \mathrm{C}$ & electrophysiological test & 3.427 .7 & [56] \\
\hline & CCAP1119/27 & $15^{\circ} \mathrm{C}$ & $\begin{array}{l}\text { STX, neoSTX, dxSTX, } \\
\text { GTX1-6, C1-2, C4 }\end{array}$ & 2732.5 fg STXs eq/cell & [60] \\
\hline & $\begin{array}{l}\text { ATTL01 } \\
\text { ATTL02 }\end{array}$ & $15^{\circ} \mathrm{C}$ & GTX $1,4,5$, C1-2 & $\begin{array}{c}5.3-44.3 \\
\text { fg STX s eq/cell }\end{array}$ & [22] \\
\hline & BAH91 & $15^{\circ} \mathrm{C}$ & STX, B1-2, C1-2 & 9.9 & [61] \\
\hline & Otsuchi Bay isolated & $15^{\circ} \mathrm{C}$ & STX, neoSTX, GTX1, C1-2 & 34.5 & [62] \\
\hline & АСТ03 & $10-30{ }^{\circ} \mathrm{C}$ & GTX3-5, C1-4 & $2.9-50.3$ & [58] \\
\hline \multirow{2}{*}{$\begin{array}{l}\text { Alexandrium } \\
\text { fundyense }\end{array}$} & BOF & $5-20^{\circ} \mathrm{C}$ & GTX1-4, STX, neoSTX & $211-544$ & [61] \\
\hline & MI & $5-20^{\circ} \mathrm{C}$ & GTX1-4, STX, neoSTX & $100-532$ & [61] \\
\hline \multirow{3}{*}{ Alexandrium tamrense } & BAH181 & $15^{\circ} \mathrm{C}$ & $\begin{array}{c}\text { GTX1-4, neoSTX, STX, } \\
\text { B1-2, C1-2 }\end{array}$ & 42.3 & [63] \\
\hline & GTPP01 & $15^{\circ} \mathrm{C}$ & $\begin{array}{c}\text { GTX1-4, neoSTX, STX, } \\
\text { B1-2, C1-2 }\end{array}$ & 33.4 & [63] \\
\hline & ATHS-95 & $17^{\circ} \mathrm{C}$ & GTX1-4, C1-4 & $1.35-2.7$ & [64] \\
\hline \multirow{6}{*}{ Alexandrium minutum } & AmSp01 & $25^{\circ} \mathrm{C}$ & GTX1, 3, 4, neoSTX & $11.2-12.8$ & [17] \\
\hline & $\mathrm{AmSp} 03$ & $25^{\circ} \mathrm{C}$ & GTX1, 4, neoSTX & $9.1-11.8$ & [17] \\
\hline & AmSp04 & $25^{\circ} \mathrm{C}$ & GTX1, 3, 4, neoSTX & $5.1-11.2$ & [17] \\
\hline & AmSp05 & $25^{\circ} \mathrm{C}$ & GTX1-4, neoSTX, dcSTX, & $3.0-9.5$ & [17] \\
\hline & AmSp17 & $25^{\circ} \mathrm{C}$ & GTX1, 3, 4, dcSTX, neoSTX & $5.6-6.3$ & [17] \\
\hline & AL3T & $15^{\circ} \mathrm{C}$ & GTX1-4 & 3 & [63] \\
\hline $\begin{array}{l}\text { Alexandrium } \\
\text { lusitanicum }\end{array}$ & BAH91 & $15^{\circ} \mathrm{C}$ & GTX1-4 & 16 & [63] \\
\hline \multirow{3}{*}{ Alexandrium affine } & AABCV-1 & $15-34^{\circ} \mathrm{C}$ & non-toxic & non-toxic & [65] \\
\hline & CCMP112 & $16-20^{\circ} \mathrm{C}$ & non-toxic & non-toxic & [3] \\
\hline & CS 312/02 & $16-20^{\circ} \mathrm{C}$ & non-toxic & non-toxic & [3] \\
\hline \multirow{2}{*}{$\begin{array}{l}\text { Alexandrium } \\
\text { andersonii }\end{array}$} & CCMP1597 & $16-20^{\circ} \mathrm{C}$ & non-toxic & non-toxic & [3] \\
\hline & CCMP2222 & $16-20^{\circ} \mathrm{C}$ & non-toxic & non-toxic & [3] \\
\hline
\end{tabular}

The STXs' toxicity of A. catenella was further compared to other toxic Alexandrium species according to cultured temperatures. It was revealed that Alexandrium sp., which belongs to the $A$. tamarense complex, can produce STXs at optimal growth temperature and lower than $20^{\circ} \mathrm{C}[63,64]$. For example, A. fundyense BOF and MI were most toxic (100-544 fmol/cell) at $5{ }^{\circ} \mathrm{C}$, and GTX 1-4 and STX with high TEF were primarily detected [61]. In addition, A. tamarense contained variants of GTX $1-4$ at $15^{\circ} \mathrm{C}$ and $17^{\circ} \mathrm{C}$, while the highest toxicity at $12{ }^{\circ} \mathrm{C}$ was analyzed [64]. Moreover, when Alexandrium minutum was incubated over a wide temperature range $\left(15-25^{\circ} \mathrm{C}\right)$, GTX3 -5 were predominantly detected at low temperature [20]. In contrast, $A$. affine and $A$. andersonii were cultured at high temperature $\left(15-34^{\circ} \mathrm{C}\right)$ without producing STXs. These results and our finding showed that the toxic Alexandrium spp. vary their STX levels and profiles depending on the strains and incubating temperatures [4,51,52]. In addition, total STXs eq and components may be affected by culture temperature, with the highest toxicity under optimal growth condition [19]. 
Cell growth and STX toxicity of Alexandrium varies depending on their growth stages and culture conditions, such as salinity, nutrients, and/or temperature $[5,17,27,66-68]$ In general, high STXs content were detected under exponential phase of optimal growth conditions [7]. This was in accordance with our results that the highest toxicity was recorded in A. catenella Alex 03 cultured at $16{ }^{\circ} \mathrm{C}$. Perhaps, when cells divide rapidly in exponential phase, cell size may decrease with increase in the division rate. Hence, cell division decreases cellular contents, thereby decreasing their cellular toxicity.

Interestingly, we found that the STXs eq/cell of Alex03 was the highest at the optimum temperature $16^{\circ} \mathrm{C}$ (maximum growth rate among three tests), and its mean cell size was much smaller than that at $12{ }^{\circ} \mathrm{C}$. The escalation in total STXs eq at $16^{\circ} \mathrm{C}$ was resulted by an increase in STX analogues at high TEF, particularly GTX1 [59]. The explanation that whether the toxicity of the cells is due to an increase in cell volume or STX production is controversial [37,67]. Previous results and our data, however, suggest that Alex03 should synthesize cellular STXs (e.g., GXT1) at low temperature, which supports optimal growth.

STXs eq and profiles of Alexandrium are partially explained by their biosynthesis gene regulation. As noted previously, sxt $A$ and $s x t G$ seem to be involved in early stage because they are considered as core genes linked to the initial process of STX production [28,45,47]. Thus, upregulation of the genes indicates the higher catalyzing rate of malonyl-CoA and arginine with increased Intermediate $A^{\prime}$ and Intermediate $B^{\prime}[34,69,70]$. After this process, STX is then converted to GTX1- 6 and C1-4 by other tailoring enzymes that are encoded by sxt cluster genes, resulting in STXs' accumulation in toxic microorganisms [34]. In the present study, significant upregulations of both $s x t A 4$ and $s x t G$ levels and STX' content were observed in A. catenella Alex03 exposed to cold shock, which showed the correlation of transcriptional responses and STX biosynthesis. This was also supported statistically by PCA, showing a positive relationship between $s x t A 4$ and $s x t G$ expression levels and total STXs eq at low temperature and cold shock but not with heat shock. Similar to our results, sxtA expression levels and total STX s $^{\prime}$ concentration decreased in cyanobacteria when exposed to $10 \mathrm{mM} \mathrm{NaCl}$ for $5 \mathrm{~h}$ [71]. Additionally, Geffroy et al. [72] suggested that transcriptional levels of $s x t A$ were related to STX ${ }^{\prime}$ content of toxic dinoflagellate $A$. minutum. In addition, both $s x t A 4$ and $s x t G$ were positively correlated with total STX ${ }^{\prime}$ production of A. minutum AmKB02 in different nutrient conditions [73]. On the other hand, results of weak correlation between mRNA levels of sxt $A$ and sxt $G$ and intracellular STXs have been reported in Mediterranean A. minutum [28]. The result indicates that STXs' synthesis genes may be regulated by post-transcriptional regulation, suggesting the inconsistency between mRNA copies and its protein abundance [28,74]. However, since they significantly correlated in stoichiometric amounts [75,76], upregulations of STXs synthesis genes can lead to increase of the related proteins.

In contrast to cold temperature, we detected low toxicity and concentrations of diverse STX analogues from $A$. catenella Alex 03 cultured at $20^{\circ} \mathrm{C}$ and heat stress. Similarly, low toxins were measured at temperature higher than the optimum growth temperature; for example, 36.5 STXs eq $\mu \mathrm{g} / \mathrm{L}$ at $23{ }^{\circ} \mathrm{C}$ and 83.3 STXs eq $\mu \mathrm{g} / \mathrm{L}$ at $30^{\circ} \mathrm{C}$ in the cyanobacterium Aphanizomenon gracile [19]. In addition, when A. catenella ACC02 was cultured at 10 to $16{ }^{\circ} \mathrm{C}$, the lowest toxin levels ( $3.46 \mathrm{fmol} \mathrm{STXs} \mathrm{eq/cell)} \mathrm{were} \mathrm{measured} \mathrm{at} 16{ }^{\circ} \mathrm{C}$ [56]. In the present research, the concentrations of GTX1 and GTX4 and sxtA4 expression levels decreased, while GTX3, STX, and neoSTX increased when A. catenella was exposed to heat stress. As mentioned above, downregulation of $s x t A 4$ and $s x t G$ may reduce biosynthesis and accumulation of STXs [34,69]. sxtG mRNA levels increased in heat stress samples, and our results complemented the results of transcriptional responses and STX analogues. These results show that temperature regulates $s x t A 4$ expression levels, thereby affecting STXs eq/cell and profiles.

STX biosynthesis and modification are accomplished by many sxt enzymes, and their activity should be affected by temperature, resulting in different toxin levels [77]. For example, as one of the tailoring enzymes, $\mathrm{N}$-sulfotransferase $(\mathrm{sxtN})$ transfers the sulfate group (3'-phospho-adenosine-5'-phosphosulfate) into GTX2/3 in the dinoflagellate Gymnodinium 
catenatum [78]. In addition, the two putative sulfotransferases sxtN and sxtSUL produce the sulfated C-toxins in the cyanobacterium Anabaena circinalis [79,80]. These represent that sxtN is responsible for transferring STX into C-toxins (C1-4) and GTX-toxins (GTX1-4), changing the STXs profile of toxin-producing species [70]. Thus, sulfotransferase activity may alter STX profile of Alex03, and it was dependent on temperature, which can be predicted by the coefficient $Q_{10}$ [81]. These results suggest that the sulfotransferase activity varies depending on the temperature, and may be more active at high temperature and heat shock in the toxic dinoflagellates Alexandrium.

\section{Materials and Methods}

\subsection{Cell culture and Adaptation}

The strain Alex03 (formerly known as LIMS-PS-2645) of A. catenella was obtained from the Marine Bio Resource Information System (MBRIS) of Korea Institute of Ocean Science \& Technology (KIOST, Jangmok, Korea). It was isolated from the Korean South sea and cultured and maintained in $\mathrm{f} / 2$ medium without silicate [82] at $20^{\circ} \mathrm{C}$ and $65 \mu \mathrm{mol}$ photons $/ \mathrm{m}^{2} / \mathrm{s}$ of photon flux density under a $12: 12 \mathrm{~h}$ light-dark cycle.

For experiments related to temperature, cells cultured at $20{ }^{\circ} \mathrm{C}$ were adapted to each test temperature. In specific, we included low temperature cultures while gradually lowering the temperature (by $0.1^{\circ} \mathrm{C}$ per day) using the standard cultures of $20^{\circ} \mathrm{C}$. Finally, three temperatures $\left(12,16\right.$, and $\left.20^{\circ} \mathrm{C}\right)$ were chosen to simulate the water temperature from March to May in the southern coasts of Korea $\left(10-23^{\circ} \mathrm{C}\right)$, because toxic Alexandrium blooms and PSP outbreaks were mostly reported during that season [49]. Each temperatureadapted culture in the exponential phase was sub-cultured in fresh $\mathrm{f} / 2$ medium for at least 6 months.

\subsection{Design for Temperature Experiments}

At the start of the experiment, each strain was inoculated at a density of $165.8 \pm$ 6.3 cells $/ \mathrm{mL}$ using fresh $\mathrm{f} / 2$ medium adapted to each temperature. The samples were either incubated at the same temperature or transferred to another incubator at different temperature for stress induction. To induce cold stress, the culture flasks incubated at $20^{\circ} \mathrm{C}$ were transferred to $16^{\circ} \mathrm{C}\left(20 \rightarrow 16^{\circ} \mathrm{C}\right)$ and $12{ }^{\circ} \mathrm{C}\left(20 \rightarrow 12{ }^{\circ} \mathrm{C}\right)$, and from $16^{\circ} \mathrm{C}$ to $12{ }^{\circ} \mathrm{C}$ $\left(16 \rightarrow 12{ }^{\circ} \mathrm{C}\right)$. Moreover, the cultures maintained at $12{ }^{\circ} \mathrm{C}$ were shifted to $16^{\circ} \mathrm{C}\left(12 \rightarrow 16^{\circ} \mathrm{C}\right)$ or $20^{\circ} \mathrm{C}\left(12 \rightarrow 20^{\circ} \mathrm{C}\right)$, and from $16^{\circ} \mathrm{C}$ into $20^{\circ} \mathrm{C}$ for inducing thermal stress. The samples were exposed to different temperatures for $72 \mathrm{~h}$ on day 15 and harvested on day 18 .

\subsection{Cell Density and Size Measurements}

Cell counts were estimated for examining growth patterns and determined every two days using a plankton-counting chamber (Matsunami Glass, Osaka, Japan) under a light microscope (Carl Zeiss Axioskop, Oberkochen, Germany). All experiments were independently performed in triplicate. Individual cells in each culture were counted using Auto T4 CellometerTM (Nexcelom Biosciences, Lawrence, MA, USA) and were then used to calculate the average cell size.

\subsection{DNA and RNA Extraction and cDNA Synthesis}

Total RNA was extracted using $200 \mathrm{~mL}$ of $A$. catenella cultures with an initial density of $6.0 \times 10^{3}$ cells $/ \mathrm{mL}$. In brief, the cells were harvested by centrifugation at $2000 \times \mathrm{g}$ for $5 \mathrm{~min}$ at $4{ }^{\circ} \mathrm{C}$, and the pellets were dissolved in $1 \mathrm{~mL}$ of TRIzol (Invitrogen, Carlsbad, CA, USA). To prevent RNA degradation, the samples were immediately frozen using liquid nitrogen and stored at $-80^{\circ} \mathrm{C}$ until RNA extraction.

For RNA extraction, the samples were physically lysed by freeze-thawing in liquid nitrogen and homogenized using zirconium beads (diameter $0.1 \mathrm{~mm}$ ) using a Mini-bead beater (BioSpec Products Inc., Bartlesville, OK, USA). The samples were additionally purified using the Mini Spin Columns of the RNeasy Mini Kit (Qiagen, Valencia, CA, USA) as per the manufacturer's instructions. After analyzing the RNA quality and quantity using 
Agilent 2100 Bioanalyzer (Agilent, Santa Clara, CA, USA), cDNA was synthesized using a TOPscript ${ }^{\mathrm{TM}} \mathrm{cDNA}$ Synthesis Kit with random hexamer and oligo(dT) ${ }^{18}$ (Enzynomics, Daejeon, Korea) for gene cloning and gene expressional experiments. cDNA templates were diluted five times with nuclease-free water for molecular experiments.

Total genomic DNA (gDNA) was extracted from the A. catenella cells using the cetyltrimethylammonium bromide (CTAB) method [83].

\subsection{Cloning of sxtA4, sxt $G$ and $28 S$ rRNA}

Partial sequences of $s x t A 4$ and $s x t G$ were retrieved from A. catenella EST data $(157,342,442$ sequence reads, $15.5 \mathrm{~Gb}$ ) obtained in our laboratory, wherein the DNA sequences were determined using the Illumina Hiseq 2500 sequencing platform. These sequences were used to design primers for gene cloning. Nested PCR was performed using specific primer pairs (Table 2) and genomic DNA and cDNA templates. The reaction conditions for PCR were as follows: pre-denaturation at $95^{\circ} \mathrm{C}$ for $5 \mathrm{~min}$; followed by 35 cycles of $95^{\circ} \mathrm{C}$ for $30 \mathrm{~s}$, $55^{\circ} \mathrm{C}$ for $30 \mathrm{~s}, 72^{\circ} \mathrm{C}$ for $1 \mathrm{~min}$ and final extension at $72{ }^{\circ} \mathrm{C}$ for $10 \mathrm{~min}$. PCR products were purified and cloned using the TOPcloner ${ }^{\mathrm{TM}}$ TA kit (Enzynomics Inc., Daejeon, Korea). Each colony was used as template for PCR amplification and subjected to DNA sequencing.

Table 2. Primers used in this study.

\begin{tabular}{|c|c|c|c|c|}
\hline Gene & Primer & Nucleotide Sequence $\left(5^{\prime} \rightarrow 3^{\prime}\right)$ & Remark & Source \\
\hline \multirow{4}{*}{$s x t A 4$} & Sxt007F & ATGCTCAACATGGGAGTCATCC & ORF & [45] \\
\hline & Sxt008R & GGGTCCAGTAGATGTTGACGATG & ORF & [45] \\
\hline & sxtA4qF & GAGCAACCCTTCGGGTATGGT & qRT-PCR & This study \\
\hline & sxtA4qR & TCAGAATGCCGAACTTCTCGTCG & qRT-PCR & This study \\
\hline \multirow{6}{*}{$s x t G$} & sxtG001F & GCCGATGTATGACTTCTACAAGAG & ORF & This study \\
\hline & sxtG002F & CATCCCAGACTGGTACATGC & ORF & This study \\
\hline & sxtG001R & CCGTATGGATGTACCTGTGC & ORF & This study \\
\hline & sxtG002R & AGAGCGTGTTCAAGTGGTAGC & ORF & This study \\
\hline & sxtGqF & GGACATGGACGAGAATAGCTG & qRT-PCR & This study \\
\hline & sxtGqR & GATGGCGAGCACGTTTATGC & qRT-PCR & This study \\
\hline \multirow{2}{*}{$\alpha$-tubulin } & TUA qF & CTTCCAGGGCTTCATGGTG & qRT-PCR & This study \\
\hline & TUA qR & AGACACGTTTGGCTCCTG & qRT-PCR & This study \\
\hline \multirow[b]{2}{*}{ Actin } & ACT-US-408-F & ACTTGATTTGCTTGGTGGGAG & qRT-PCR & [84] \\
\hline & ACT-US-645-R & AAGTCCAAGGAAGGAAGCATC & qRT-PCR & [84] \\
\hline \multirow{2}{*}{$28 S$ rRNA } & 28F01 & \multirow{2}{*}{$\begin{array}{l}\text { CCGCTGAATTTAAGCATATAAGTAAGC } \\
\text { CTTGGTCCGTGTTTCAAGAC }\end{array}$} & C rRNA & [85] \\
\hline & 28R691 & & rRNA & [85] \\
\hline
\end{tabular}

\subsection{Gene Characterization and Phylogenetic Analysis}

The test species was identified by comparing the $28 \mathrm{~S}$ rRNA sequence with that of other dinoflagellates obtained from GenBank and related researches [51]. The correct frames of two sxt genes were determined using BLASTx. The deduced amino acid sequences of $s x t A 4$ and $s x t G$ were analyzed using the PROSITE-ExPASy Bioinformatics Resource portal (http:/ / prosite.expasy.org/, accessed 4 January 2021) and the Interpro online tool (https: //www.ebi.ac.uk/interpro/, accessed 4 January 2021) to identify the conserved domains.

Phylogenetic analyses were performed with sxt amino acid sequences of $A$. catenella Alex03 and related organisms. Each sequence matrix was properly aligned using Clustal X 2.0 (Conway Institute UCD Dublin, Dublin, Ireland) [86], and the final alignment of the sxtA 4 and sxtG dataset consisted of 23 and 35 taxa and contained 236 and 256 amino acids, respectively. Phylogenetic tree derived from each dataset were constructed using the maximum likelihood (ML) algorithm, and the best-fitted model (LG+G) in MEGA X [87]. A bootstrap consensus tree inferred from 1000 replicates was used for taxa analysis.

\subsection{Quantitative Real-Time PCR}

Quantitative real-time PCR (qRT-PCR) was performed using the TOPreal qPCR $2 \times$ PreMIX SYBR Green Kit (Enzynomics Inc., Daejeon, Korea) in a CFX96 Real-Time PCR 
Detection System (Bio-Rad, Hercules, CA, USA). The reaction mixtures were prepared as follows: each of forward and reverse primer $(10 \mathrm{pmol} / \mu \mathrm{L} ; 1 \mu \mathrm{L})$, diluted cDNA $(2 \mu \mathrm{L})$, TOPreal qPCR $2 \times$ PreMIX buffer (SYBR Green with high ROX, $10 \mu \mathrm{L}$ ), and distilled water $(6 \mu \mathrm{L})$. The reaction was performed as follows: $4 \mathrm{~min}$ at $50{ }^{\circ} \mathrm{C} ; 10 \mathrm{~min}$ at $95^{\circ} \mathrm{C}$; followed by 40 cycles of $10 \mathrm{~s}$ at $95^{\circ} \mathrm{C}, 15 \mathrm{~s}$ at $60^{\circ} \mathrm{C}$, and $15 \mathrm{~s}$ at $72{ }^{\circ} \mathrm{C}$. Each reaction was performed in triplicate to calculate the mean value. Specificity of amplification was identified by the melting curve generated by heating the sample from $65^{\circ} \mathrm{C}$ to $95^{\circ} \mathrm{C}$. Primer efficiency was calculated from the standard curve using the threshold cycle $(\mathrm{Ct})$ values for a 10 -fold dilution series of the cDNA. Among reference genes, $\alpha$ tubulin (TUA) was used as internal controls for data normalization. Results were analyzed using the Student's t-test in SPSS software (Version 19.0; IBM Corp., Armonk, NY, USA).

\subsection{High-Pressure Liquid Chromatography-Fluorescence Detection (HPLC-FLD)}

We harvested A. catenella from $100 \mathrm{~mL}$ of culture by centrifugation at $2000 \times g$ for $10 \mathrm{~min}$. The pellets were immediately resuspended in $0.01 \mathrm{M} \mathrm{HCl}(\mathrm{pH} 3.0)$ and homogenized using a bead crusher (Taitec Corporation, Nishikata, Japan). The homogenized samples were boiled at $95^{\circ} \mathrm{C}$ for $5 \mathrm{~min}$. All samples were filtered through a 0.2-micrometer GVS syringe filter (GVS, Bologna, Italia) to remove cell debris.

Standard solutions including GTX1-4,6, C1-2, dcGTX2-3, STX, neoSTX, and dcSTX purchased from National Research Council Canada (NRC; Halifax, NS, Canada). STX ${ }^{\prime}$ analysis was performed using a HPLC-FLD system (Waters, Milford, MA, USA) and the post-column method with a slight modification of the process described by Rey et al. [88]. The fluorescence detector operated at an excitation wavelength of $330 \mathrm{~nm}$ and emission was scanned at $390 \mathrm{~nm}$. STX analogues were separated using a Hypercarb ${ }^{\circledR}$ column (150 mm $\times 2.1 \mathrm{~mm}$ i.d., $5 \mu \mathrm{m}$; Thermo Scientific, Madrid, Spain) and quantified using a 5-point calibration curve prepared using the reference standards. The concentrations of total STXs were calculated as STXs equivalent per cells (STXs eq fmol/cell) by referring to the TEF. Each STX analog has a different TEF value and the total STXs eq calculation was based on FAO/WHO [59]. The TEF sets the toxicity of STX to 1 and calculates the relative toxicity of the other derivatives.

\subsection{Statistical Analysis and Principal Component Analysis (PCA)}

Statistical analyses were performed using the SPSS statistical package (Version 19.0; IBM Corp., Armonk, NY, USA). Mean and standard errors were calculated for each treatment, and significant differences were determined with one-way analysis of variance (ANOVA), followed by the Student-Newman-Keuls multiple comparisons test. Probability (p) values of one-way ANOVA tests were indicated as ${ }^{*} p<0.05,{ }^{* *} p<0.01$, and ${ }^{* * *} p<0.001$. $p<0.05$ was considered as statistically significant.

In addition, principal component analysis (PCA) was performed to evaluate the relationship among tested variables, such as water temperatures, cell size, and STX biosynthesis (total STXs eq and relative expression of $s x t A 4$ and $s x t G$ ) using the Paleontological Statistics package (Past v.4.03; Natural History Museum, Blindern, Norway).

\section{Conclusions}

This work first reported STX $\mathrm{s}^{\prime}$ toxicity and contents in the toxic dinoflagellate $A$. catenella Alex03 under different temperatures and the possible relationships with the regulation of two core genes $s x t A 4$ and $s x t G$. The optimal temperature for Alex03 was $16{ }^{\circ} \mathrm{C}$, exhibiting the highest growth rate and cellular STXs' content. When Alex03 was exposed to low temperatures and cold stress, the total STXs eq increased notably with increased GTX1 and sxtA4 and sxtG transcriptional levels (Figure 6). Conversely, thermal shock lowered STXs eq/cell, but a wider variety of STX analogues were detected with downregulation of sxtA4. Statistical analysis demonstrated that $s x t A 4$ expression was correlated with STXs eq in low temperature and cold shock samples, whereas $s x t G$ was sensitive to temperature changes. These results were in accordance with the results of field 
monitoring data, i.e., most PST contamination of shellfish by A. catenella occurred in spring and autumn $\left(8.2-15^{\circ} \mathrm{C}\right)$ in Korean coasts [89]. In addition, resting cysts of the Alexandrium spp. germinated in November at $19.1-19.6^{\circ} \mathrm{C}$ [50], and optimal growth temperature for A. catenella was recorded at $10-20^{\circ} \mathrm{C}$. Based on these field data and the results, we could conclude that temperature affected the STXs and the regulation of their biosynthesis genes to the highest level at optimal and cold temperatures in A. catenella. STX biosynthesis and modification involves many enzymes and their functional gene regulations, and thus, further researches are necessary to understand the whole transcriptional responses of STX synthesis genes in the future.

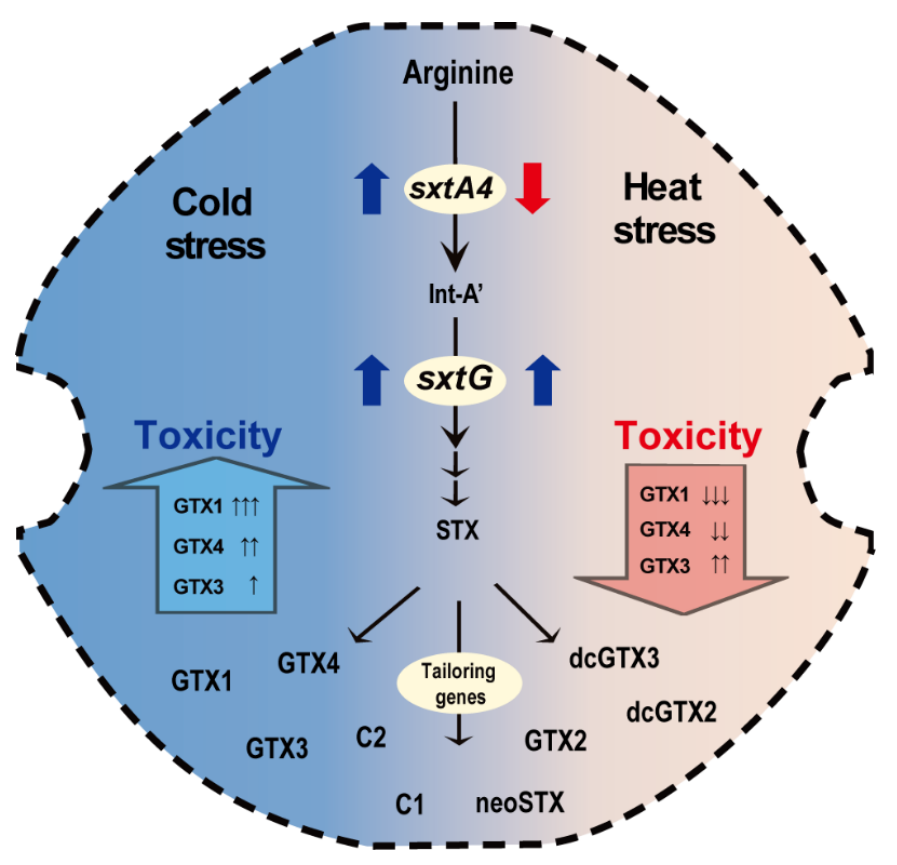

Figure 6. A schematic representation of the putative saxitoxin metabolic pathway in Alexandrium catenella. The transcriptional levels of the core genes $s x t A 4$ and $s x t G$ regulate STX biosynthesis and are altered by water temperature. Cold stress upregulated both $s x t A 4$ and $s x t G$, leading to higher STX production, whereas heat stress downregulated $s x t A 4$ to lower the toxicity. Various analogues were analyzed.

Author Contributions: Conceptualization, experiment, data analyses, writing-original draft preparation, H.K.; formal analysis, validation, H.P.; writing-review and editing, H.W.; methodology, H.Y.Y.; project administration, review and editing, J.P.; conceptualization, supervision, data analyses, writing-review and editing, J.-S.K. All authors have read and agreed to the published version of the manuscript.

Funding: This work was supported by the National Research Foundation of Korea (NRF) grant funded by the Korea government (MSIT) (no. 2020R1A2C2013373), and a part of the project titled 'Improvement of management strategies on marine disturbing ecosystems and harmful organisms' (no. 20190518) funded by the Ministry of Oceans and Fisheries, Korea.

Institutional Review Board Statement: Not applicable.

Informed Consent Statement: Not applicable.

Data Availability Statement: The data presented in this study are available on request from the corresponding authors. In addition, the data that support the findings of this study are openly available in GenBank with the accession numbers MW882944, MW884258, and MW884259.

Acknowledgments: We thank T. Kim for helping with microscopic observation.

Conflicts of Interest: The authors declare no conflict of interest. 


\section{References}

1. Taylor, F.J.R. Ecology of dinoflagellates. In The Biology of Dinoflagellates; Blackwell Scientific Publications: Oxford, UK, 1987.

2. Taylor, F.J.R.; Hoppenrath, M.; Saldarriaga, J.F. Dinoflagellate diversity and distribution. Biodiver. Conserv. 2008, 17, 407-418. [CrossRef]

3. Murray, S.A.; Wiese, M.; Stüken, A.; Brett, S.; Kellmann, R.; Hallegraeff, G.; Neilan, B.A. sxtA-based quantitative molecular assay to identify saxitoxin-producing harmful algal blooms in marine waters. Appl. Environ. Microbiol. 2011, 77. [CrossRef]

4. Murray, S.A.; Wiese, M.; Neilan, B.A.; Orr, R.J.; de Salas, M.; Brett, S.; Hallegraeff, G. A reinvestigation of saxitoxin production and $s x t A$ in the 'non-toxic' Alexandrium tamarense Group V clade. Harmful Algae 2012, 18, 96-104. [CrossRef]

5. Anderson, D.M.; Alpermann, T.J.; Cembella, A.D.; Collos, Y.; Masseret, E.; Montresor, M. The globally distributed genus Alexandrium: Multifaceted roles in marine ecosystems and impacts on human health. Harmful Algae 2012, 14, 10-35. [CrossRef] [PubMed]

6. Wang, D.Z. Neurotoxins from marine dinoflagellates: A brief review. Mar. Drugs 2008, 6, 349-371. [CrossRef] [PubMed]

7. Reich, A.; Lazensky, R.; Faris, J.; Fleming, L.E.; Kirkpatrick, B.; Watkins, S.; Ullmannd, S.; Kohlere, K.; Hoagland, P. Assessing the impact of shellfish harvesting area closures on neurotoxic shellfish poisoning (NSP) incidence during red tide (Karenia brevis) blooms. Harmful Algae 2015, 43, 13-19. [CrossRef]

8. Vlamis, A.; Katikou, P.; Rodriguez, I.; Rey, V.; Alfonso, A.; Papazachariou, A.; Zacharaki, T.; Botana, A.M.; Botana, L.M. First detection of tetrodotoxin in Greek shellfish by UPLC-MS/MS potentially linked to the presence of the dinoflagellate Prorocentrum minimum. Toxins 2015, 7, 1779-1807. [CrossRef]

9. Glibert, P.M.; Pitcher, G. Global Ecology and Oceanography of Harmful Algal Blooms, Science Plan; SCOR and IOC: Baltimore, MD, USA; Paris, France, 2001; p. 87.

10. De Carvalho, M.; Jacinto, J.; Ramos, N.; de Oliveira, V.; e Melo, T.P.; de Sá, J. Paralytic shellfish poisoning: Clinical and electrophysiological observations. J. Neurol. 1998, 245, 551-554. [CrossRef] [PubMed]

11. Catterall, W.A. Neurotoxins that act on voltage-sensitive sodium channels in excitable membranes. Annu. Rev. Pharmacol. 1980, 20, 15-43. [CrossRef]

12. Cestèle, S.; Catterall, W.A. Molecular mechanisms of neurotoxin action on voltage-gated sodium channels. Biochimie 2000, 82, 883-892. [CrossRef]

13. Wang, J.; Salata, J.J.; Bennett, P.B. Saxitoxin is a gating modifier of HERG K+ channels. J. Gen. Physiol. 2003, 121, 583-598. [CrossRef] [PubMed]

14. Schantz, E.J.; Mold, J.; Stanger, D.; Shavel, J.; Riel, F.; Bowden, J.; Lynch, J.; Wyler, R.; Riegel, B.; Sommer, H. Paralytic shellfish poison VI. A procedure for the isolation and purification of the poison from toxic clams and mussel tissues. J. Am. Chem. Soc. 1957, 79, 5230-5235. [CrossRef]

15. Shumway, S.E. Phycotoxin-related shellfish poisoning: Bivalve molluscs are not the only vectors. Rev. Fish. Sci. 1995, 3, 1-31. [CrossRef]

16. Usup, G.; Pin, L.C.; Ahmad, A.; Teen, L.P. Alexandrium (Dinophyceae) species in Malaysian waters. Harmful Algae 2002, 1, $265-275$. [CrossRef]

17. Lim, P.T.; Leaw, C.P.; Usup, G.; Kobiyama, A.; Koike, K.; Ogata, T. Effects of light and temperature on growth, nitrate uptake, and toxin production of two tropical dinoflagellates: Alexandrium tamiyavanichii and Alexandrium minutum (Dinophyceae). J. Phycol. 2006, 42, 786-799. [CrossRef]

18. Hattenrath-Lehmann, T.K.; Smith, J.L.; Wallace, R.B.; Merlo, L.R.; Koch, F.; Mittelsdorf, H.; Goleski, J.A.; Anderson, D.M.; Gobler, C.J. The effects of elevated $\mathrm{CO}_{2}$ on the growth and toxicity of field populations and cultures of the saxitoxin-producing dinoflagellate, Alexandrium fundyense. Limnol. Oceanogr. 2015, 60, 198-214. [CrossRef] [PubMed]

19. Cirés, S.; Delgado, A.; González-Pleiter, M.; Quesada, A. Temperature influences the production and transport of saxitoxin and the expression of sxt genes in the cyanobacterium Aphanizomenon gracile. Toxins 2017, 9, 322. [CrossRef] [PubMed]

20. Hwang, D.F.; Lu, Y.H. Influence of environmental and nutritional factors on growth, toxicity, and toxin profile of dinoflagellate Alexandrium minutum. Toxicon 2000, 38, 1491-1503. [CrossRef]

21. Vargas, S.R.; dos Santos, P.V.; Bottino, F.; do Carmo Calijuri, M. Effect of nutrient concentration on growth and saxitoxin production of Raphidiopsis raciborskii (Cyanophyta) interacting with Monoraphidium contortum (Chlorophyceae). J. Appl. Phycol. 2020, 32, 421-430. [CrossRef]

22. Lilly, E.L.; Kulis, D.M.; Gentien, P.; Anderson, D.M. Paralytic shellfish poisoning toxins in France linked to a human-introduced strain of Alexandrium catenella from western Pacific: Evidence from DNA and toxin analysis. J. Plankton. Res. 2002, 24, 443-452. [CrossRef]

23. Vila, M.; Giacobbe, M.G.; Masó, M.; Gangemi, E.; Penna, A.; Sampedro, N.; Azzaro, F.; Camp, J.; Galluzzi, L.; Galluzzi, L. A comparative study on recurrent blooms of Alexandrium minutum in two Mediterranean coastal areas. Harmful Algae 2005, 4, 673-695. [CrossRef]

24. Penna, A.; Garcés, E.; Vila, M.; Giacobbe, M.G.; Fraga, S.; Lugliè, A.; Bravo, I.; Bertozzini, E.; Vernesi, C. Alexandrium catenella (Dinophyceae), a toxic ribotype expanding in the NW Mediterranean Sea. Mar. Biol. 2005, 148, 13-23. [CrossRef]

25. Genovesi, B.; Shin-Grzebyk, M.S.; Grzebyk, D.; Laabir, M.; Gagnaire, P.A.; Vaquer, A.; Pastoureaud, A.; Lasserre, B.; Collos, Y.; Berrebi, P.; et al. Assessment of cryptic species diversity within blooms and cyst bank of the Alexandrium tamarense complex (Dinophyceae) in a Mediterranean lagoon facilitated by semi-multiplex PCR. J. Plankton. Res. 2011, 33, 405-414. [CrossRef] 
26. Vandersea, M.W.; Kibler, S.R.; Tester, P.A.; Holderied, K.; Hondolero, D.E.; Powell, K.; Baird, S.; Doroff, A.; Dugan, D.; Litaker, R.W. Environmental factors influencing the distribution and abundance of Alexandrium catenella in Kachemak bay and lower cook inlet, Alaska. Harmful Algae 2018, 77, 81-92. [CrossRef]

27. Lim, P.T.; Ogata, T. Salinity effect on growth and toxin production of four tropical Alexandrium species (Dinophyceae). Toxicon 2005, 45, 699-710. [CrossRef]

28. Perini, F.; Galluzzi, L.; Dell'Aversano, C.; Iacovo, E.D.; Tartaglione, L.; Ricci, F.; Forino, M.; Ciminiello, P.; Penna, A. SxtA and $s x t G$ gene expression and toxin production in the Mediterranean Alexandrium minutum (Dinophyceae). Mar. Drugs 2014, 12, 5258-5276. [CrossRef] [PubMed]

29. Eckford-Soper, L.K.; Bresnan, E.; Lacaze, J.P.; Green, D.H.; Davidson, K. The competitive dynamics of toxic Alexandrium fundyense and non-toxic Alexandrium tamarense: The role of temperature. Harmful Algae 2016, 53, 135-144. [CrossRef]

30. Wang, D.Z.; Hsieh, D.P. Effects of nitrate and phosphate on growth and C2 toxin productivity of Alexandrium tamarense CI01 in culture. Mar. Pollut. Bull. 2002, 45, 286-289. [CrossRef]

31. Kellmann, R.; Mihali, T.K.; Jeon, Y.J.; Pickford, R.; Pomati, F.; Neilan, B.A. Biosynthetic intermediate analysis and functional homology reveal a saxitoxin gene cluster in cyanobacteria. Appl. Environ. Microbiol. 2008, 74, 4044-4053. [CrossRef] [PubMed]

32. Mihali, T.K.; Kellmann, R.; Neilan, B.A. Characterisation of the paralytic shellfish toxin biosynthesis gene clusters in Anabaena circinalis AWQC131C and Aphanizomenon sp. NH-5. BMC Biochem. 2009, 10, 1-13. [CrossRef] [PubMed]

33. D'Agostino, P.M.; Al-Sinawi, B.; Mazmouz, R.; Muenchhoff, J.; Neilan, B.A.; Moffitt, M.C. Identification of promoter elements in the Dolichospermum circinale AWQC131C saxitoxin gene cluster and the experimental analysis of their use for heterologous expression. BMC Microbiol. 2020, 20,1-11. [CrossRef] [PubMed]

34. Cho, Y.; Tsuchiya, S.; Omura, T.; Koike, K.; Oikawa, H.; Konoki, K.; Oshima, Y.; Yotsu-Yamashita, M. Metabolomic study of saxitoxin analogues and biosynthetic intermediates in dinoflagellates using $15 \mathrm{~N}$-labelled sodium nitrate as a nitrogen source. Sci. Rep. 2019, 9, 1-11.

35. Akbar, M.A.; Mohd Yusof, N.Y.; Tahir, N.I.; Ahmad, A.; Usup, G.; Sahrani, F.K.; Bunawan, H. Biosynthesis of saxitoxin in marine dinoflagellates: An omics perspective. Mar. Drugs. 2020, 18, 103. [CrossRef] [PubMed]

36. Wisecaver, J.H.; Brosnahan, M.L.; Hackett, J.D. Horizontal gene transfer is a significant driver of gene innovation in dinoflagellates. Genome Biol. Evol. 2013, 5, 2368-2381. [CrossRef]

37. Zhang, C.; Lin, S.; Huang, L.; Lu, W.; Li, M.; Liu, S. Suppression subtraction hybridization analysis revealed regulation of some cell cycle and toxin genes in Alexandrium catenella by phosphate limitation. Harmful Algae 2014, 39, 26-39. [CrossRef]

38. Zhang, Y.; Zhang, S.F.; Lin, L.; Wang, D.Z. Whole transcriptomic analysis provides insights into molecular mechanisms for toxin biosynthesis in a toxic dinoflagellate Alexandrium catenella (ACHK-T). Toxins 2017, 9, 213. [CrossRef]

39. Guo, R.; Wang, H.; Suh, Y.S.; Ki, J.S. Transcriptomic profiles reveal the genome-wide responses of the harmful dinoflagellate Cochlodinium polykrikoides when exposed to the algicide copper sulfate. BMC Genom. 2016, 17, 1-16. [CrossRef] [PubMed]

40. Verma, A.; Barua, A.; Ruvindy, R.; Savela, H.; Ajani, P.A.; Murray, S.A. The genetic basis of toxin biosynthesis in dinoflagellates. Microorganisms 2019, 7, 222. [CrossRef]

41. Wang, H.; Guo, R.; Lim, W.A.; Allen, A.E.; Ki, J.S. Comparative transcriptomics of toxin synthesis genes between the non-toxin producing dinoflagellate Cochlodinium polykrikoides and toxigenic Alexandrium pacificum. Harmful Algae 2020, 93. [CrossRef] [PubMed]

42. Wang, H.; Kim, H.; Ki, J.S. Transcriptome survey and toxin measurements reveal evolutionary modification and loss of saxitoxin biosynthesis genes in the dinoflagellates Amphidinium carterae and Prorocentrum micans. Ecotoxicol. Environ. Saf. 2020, 195. [CrossRef] [PubMed]

43. Wang, H.; Kim, H.; Ki, J.S. Transcriptomic identification and expression analysis of cold shock domain protein (CSP) genes in the marine dinoflagellate Prorocentrum minimum. J. Appl. Phycol. 2021, 33, 843-845. [CrossRef]

44. Lukowski, A.L.; Mallik, L.; Hinze, M.E.; Carlson, B.M.; Ellinwood, D.C.; Pyser, J.B.; Koutmos, M.; Narayan, A.R. Substrate promiscuity of a paralytic shellfish toxin amidinotransferase. ACS Chem. Biol. 2020, 15, 626-631. [CrossRef] [PubMed]

45. Stüken, A.; Orr, R.J.; Kellmann, R.; Murray, S.A.; Neilan, B.A.; Jakobsen, K.S. Discovery of nuclear-encoded genes for the neurotoxin saxitoxin in dinoflagellates. PLOS ONE 2011, 6, e20096. [CrossRef]

46. Murray, S.A.; Ruvindy, R.; Kohli, G.S.; Anderson, D.M.; Brosnahan, M.L. Evaluation of $s x t A$ and rDNA qPCR assays through monitoring of an inshore bloom of Alexandrium catenella Group 1. Sci. Rep. 2019, 9, 1-12. [CrossRef]

47. Orr, R.J.; Stüken, A.; Murray, S.A.; Jakobsen, K.S. Evolution and distribution of saxitoxin biosynthesis in dinoflagellates. Mar. Drugs 2013, 11, 2814-2828. [CrossRef] [PubMed]

48. Mendoza-Flores, A.; Leyva-Valencia, I.; Band-Schmidt, C.J.; Galindo-Sánchez, C.E.; Bustillos-Guzmán, J.J. Identification of the gene sxtA (domains sxtA1 and sxtA4) in Mexican strains of Gymnodinium catenatum (Dinophyceae) and their evolution. Front. Mar. Sci. 2018, 5. [CrossRef]

49. Oh, S.J.; Park, J.A.; Kwon, H.K.; Yang, H.S.; Lim, W. Ecophysiological studies on the population dynamics of two toxic dinoflagellates Alexandrium tamarense and Alexandrium catenella isolated from the southern coast of Korea-I. Effects of temperature and salinity on the growth. J. Korean Soc. Mar. Environ. Energy 2012, 15, 133-141. [CrossRef]

50. Shin, H.H.; Li, Z.; Kim, E.S.; Park, J.W.; Lim, W.A. Which species, Alexandrium catenella (Group I) or A. pacificum (Group IV), is really responsible for past paralytic shellfish poisoning outbreaks in Jinhae-Masan Bay, Korea? Harmful Algae 2017, 68, 31-39. [CrossRef] [PubMed] 
51. D'Agostino, P.M.; Song, X.; Neilan, B.A.; Moffitt, M.C. Comparative proteomics reveals that a saxitoxin-producing and a nontoxic strain of Anabaena circinalis are two different ecotypes. J. Proteome Res. 2014, 13, 1474-1484. [CrossRef]

52. D'Agostino, P.M.; Song, X.; Neilan, B.A.; Moffitt, M.C. Proteogenomics of a saxitoxin-producing and non-toxic strain of Anabaena circinalis (cyanobacteria) in response to extracellular $\mathrm{NaCl}$ and phosphate depletion. Environ. Microbiol. 2016, 18, 461-476. [CrossRef]

53. John, U.; Litaker, R.W.; Montresor, M.; Murray, S.; Brosnahan, M.L.; Anderson, D.M. Formal revision of the Alexandrium tamarense species complex (Dinophyceae) taxonomy: The introduction of five species with emphasis on molecular-based (rDNA) classification. Protist 2014, 165, 779-804. [CrossRef] [PubMed]

54. Lilly, E.L.; Halanych, K.M.; Anderson, D.M. Species boundaries and global biogeography of the Alexandrium tamarense complex (Dinophyceae). J. Phycol. 2007, 43, 1329-1338. [CrossRef]

55. Mertens, K.N.; Adachi, M.; Anderson, D.M.; Band-Schmidt, C.J.; Bravo, I.; Brosnahan, M.L.; Bolch, C.J.S.; Calado, A.J.; CarbonellMoore, M.C.; Chomérat, N. Morphological and phylogenetic data do not support the split of Alexandrium into four genera. Harmful Algae 2020, 98. [CrossRef] [PubMed]

56. Navarro, J.M.; Munoz, M.G.; Contreras, A.M. Temperature as a factor regulating growth and toxin content in the dinoflagellate Alexandrium catenella. Harmful Algae 2006, 5, 762-769. [CrossRef]

57. Laabir, M.; Jauzein, C.; Genovesi, B.; Masseret, E.; Grzebyk, D.; Cecchi, P.; Vaquer, A.; Perrin, Y.; Collos, Y. Influence of temperature, salinity and irradiance on the growth and cell yield of the harmful red tide dinoflagellate Alexandrium catenella colonizing Mediterranean waters. J. Plankton Res. 2011, 33, 1550-1563. [CrossRef]

58. Laabir, M.; Collos, Y.; Masseret, E.; Grzebyk, D.; Abadie, E.; Savar, V.; Sibat, M.; Amzil, Z. Influence of environmental factors on the paralytic shellfish toxin content and profile of Alexandrium catenella (Dinophyceae) isolated from the Mediterranean Sea. Mar. Drugs 2013, 11, 1583. [CrossRef] [PubMed]

59. Food and Agriculture Organization (FAO)/World Health Organization (WHO). Technical Paper on Toxicity Equivalency Factors for Marine Biotoxins Associated with Bivalve Molluscs; FAO: Rome, Italy, 2016; p. 108.

60. Abdulhussain, A.H.; Cook, K.B.; Turner, A.D.; Lewis, A.M.; Elsafi, M.A.; Mayor, D.J. The influence of the toxin producing Dinoflagellate, Alexandrium catenella (1119/27), on the feeding and survival of the marine Copepod, Acartia tonsa. Harmful Algae 2020, 98. [CrossRef]

61. Etheridge, S.M.; Roesler, C.S. Effects of temperature, irradiance, and salinity on photosynthesis, growth rates, total toxicity, and toxin composition for Alexandrium fundyense isolates from the Gulf of Maine and Bay of Fundy. Deep Sea Res. Part II Top. Stud. Oceanogr. 2005, 52, 2491-2500. [CrossRef]

62. Sekiguchi, K.; Ogata, T.; Kaga, S.; Yoshida, M.; Fukuyo, Y.; Kodama, M. Accumulation of paralytic shellfish toxins in the scallop Patinopecten yessoensis caused by the dinoflagellate Alexandrium catenella in Otsuchi Bay, Iwate Prefecture, northern Pacific coast of Japan. Fish. Sci. 2001, 67, 1157-1162. [CrossRef]

63. Tillmann, U.; John, U. Toxic effects of Alexandrium spp. on heterotrophic dinoflagellates: An allelochemical defence mechanism independent of PSP-toxin content. Mar. Ecol. Prog. Ser. 2002, 230, 47-58. [CrossRef]

64. Hamasaki, K.; Horie, M.; Tokimitsu, S.; Toda, T.; Taguchi, S. Variability in toxicity of the dinoflagellate Alexandrium tamarense isolated from Hiroshima Bay, western Japan, as a reflection of changing environmental conditions. J. Plankton Res. 2001, 23, 271-278. [CrossRef]

65. Band-Schmidt, C.J.; Lilly, E.L.; Anderson, D.M. Identification of Alexandrium affine and A. margalefii (Dinophyceae) using DNA sequencing and LSU rDNA-based RFLP-PCR assays. Phycologia 2003, 42, 261-268. [CrossRef]

66. Anderson, D.M.; Kulis, D.M.; Sullivan, J.J.; Hall, S.; Lee, C. Dynamics and physiology of saxitoxin production by the dinoflagellates Alexandrium spp. Mar. Biol. 1990, 104, 511-524. [CrossRef]

67. Lim, P.T.; Leaw, C.P.; Kobiyama, A.; Ogata, T. Growth and toxin production of tropical Alexandrium minutum halim (Dinophyceae) under various nitrogen to phosphorus ratios. J. Appl. Phycol. 2010, 22, 203-210. [CrossRef]

68. Jensen, M.Ø.; Moestrup, Ø. Autecology of the toxic dinoflagellate Alexandrium ostenfeldii: Life history and growth at different temperatures and salinities. Eur. J. Phycol. 1997, 32, 9-18. [CrossRef]

69. Cho, Y.; Ogawa, M.; Yotsu-Yamashita, M.; Oshima, Y. Effect of 5-fluoro-2'-deoxyuridine on toxin production and cell cycle regulation in marine dinoflagellate, Alexandrium tamarense. Harmful Algae 2014, 32, 64-72. [CrossRef]

70. Tsuchiya, S.; Cho, Y.; Konoki, K.; Nagasawa, K.; Oshima, Y.; Yotsu-Yamashita, M. Biosynthetic route towards saxitoxin and shunt pathway. Sci. Rep. 2016, 6, 1-9. [CrossRef] [PubMed]

71. Ongley, S.E.; Pengelly, J.J.; Neilan, B.A. Elevated Na+ and $\mathrm{pH}$ influence the production and transport of saxitoxin in the cyanobacteria Anabaena circinalis AWQC131C and Cylindrospermopsis raciborskii T3. Environ. Microbiol. 2016, 18, 427-438. [CrossRef] [PubMed]

72. Geffroy, S.; Lechat, M.M.; Le Gac, M.; Rovillon, G.A.; Marie, D.; Bigeard, E.; Malo, F.; Amzil, Z.; Guillou, L.; Caruana, A. From the sxtA4 gene to saxitoxin production: What controls the variability among Alexandrium minutum and Alexandrium pacificum strains? Front. Microbiol. 2021, 12, 341-356. [CrossRef] [PubMed]

73. Hii, K.S.; Lim, P.T.; Kon, N.F.; Takata, Y.; Usup, G.; Leaw, C.P. Physiological and transcriptional responses to inorganic nutrition in a tropical Pacific strain of Alexandrium minutum: Implications for the saxitoxin genes and toxin production. Harmful Algae 2016, 56, 9-21. [CrossRef] 
74. Wiese, M.; Murray, S.A.; Alvin, A.; Neilan, B.A. Gene expression and molecular evolution of $s x t A 4$ in a saxitoxin producing dinoflagellate Alexandrium catenella. Toxicon 2014, 92, 102-112. [CrossRef]

75. Jansen, R.; Greenbaum, D.; Gerstein, M. Relating whole-genome expression data with protein-protein interactions. Genome Res. 2002, 12, 37-46. [CrossRef]

76. Greenbaum, D.; Colangelo, C.; Williams, K.; Gerstein, M. Comparing protein abundance and mRNA expression levels on a genomic scale. Genome Biol. 2003, 4, 1-8. [CrossRef] [PubMed]

77. Band-Schmidt, C.J.; Bustillos-Guzmán, J.J.; Hernández-Sandoval, F.E.; Núñez-Vázquez, E.J.; López-Cortés, D.J. Effect of temperature on growth and paralytic toxin profiles in isolates of Gymnodinium catenatum (Dinophyceae) from the Pacific coast of Mexico. Toxicon 2014, 90, 199-212. [CrossRef] [PubMed]

78. Sako, Y.; Yoshida, T.; Uchida, A.; Arakawa, O.; Noguchi, T.; Ishida, Y. Purification and characterization of a sulfotransferase specific to $\mathrm{N}-21$ of saxitoxin and gonyautoxin $2+3$ from the toxic dinoflagellate Gymnodinium catenatum (Dinophyceae). J. Phycol. 2001, 37, 1044-1051. [CrossRef]

79. Llewellyn, L.E.; Negri, A.P.; Doyle, J.; Baker, P.D.; Beltran, E.C.; Neilan, B.A. Radioreceptor assays for sensitive detection and quantitation of saxitoxin and its analogues from strains of the freshwater cyanobacterium, Anabaena circinalis. Environ. Sci. Technol. 2001, 35, 1445-1451. [CrossRef] [PubMed]

80. Soto-Liebe, K.; Murillo, A.A.; Krock, B.; Stucken, K.; Fuentes-Valdés, J.J.; Trefault, N.; Cembella, A.; Vásquez, M. Reassessment of the toxin profile of Cylindrospermopsis raciborskii $\mathrm{T} 3$ and function of putative sulfotransferases in synthesis of sulfated and sulfonated PSP toxins. Toxicon 2010, 56, 1350-1361. [CrossRef]

81. Atkin, O.K.; Tjoelker, M.G. Thermal acclimation and the dynamic response of plant respiration to temperature. Trends Plant. Sci. 2003, 8, 343-351. [CrossRef]

82. Guillard, R.R.L. Culture of phytoplankton for feeding marine invertebrates. In Culture of Marine Invertebrate Animals, 1st ed.; Smith, W.L., Chanley, M.H., Eds.; Springer: Boston, MA, USA, 1975; pp. $29-60$.

83. Richards, E.; Reichardt, M.; Rogers, S. Preparation of genomic DNA from plant tissue. In Current Protocols in Molecular Biology; Ausubel, F.M., Brent, R., Kingston, R.E., Moore, D.D., Seidman, J.G., Smith, J.A., Struhl, K., Eds.; John Wiley \& Sons, Inc.: Hoboken, NJ, USA, 1994; pp. 2-3.

84. Ruvindy, R.; Bolch, C.J.; MacKenzie, L.; Smith, K.F.; Murray, S.A. qPCR assays for the detection and quantification of multiple paralytic shellfish toxin-producing species of Alexandrium. Front. Microbiol. 2018, 9. [CrossRef]

85. Thangaraj, P.; Park, T.G.; Ki, J.S. Molecular cloning reveals co-occurring species behind red tide blooms of the harmful dinoflagellate Cochlodinium polykrikoides. Biochem. Syst. Ecol. 2017, 70, 29-34. [CrossRef]

86. Larkin, M.A.; Blackshields, G.; Brown, N.P.; Chenna, R.; McGettigan, P.A.; McWilliam, H.; Valentin, F.; Wallace, I.M.; Wilm, A.; Lopez, R.; et al. Clustal W and clustal X version 2.0. Bioinformatics 2007, 23, 2947-2948. [CrossRef] [PubMed]

87. Kumar, S.; Stecher, G.; Li, M.; Knyaz, C.; Tamura, K. MEGA X: Molecular evolutionary genetics analysis across computing platforms. Mol. Biol. Evol. 2018, 35, 1547-1549. [CrossRef] [PubMed]

88. Rey, V.; Botana, A.M.; Antelo, A.; Alvarez, M.; Botana, L.M. Rapid analysis of paralytic shellfish toxins and tetrodotoxins by liquid chromatography-tandem mass spectrometry using a porous graphitic carbon column. Food chem. 2018, 269, 166-172. [CrossRef] [PubMed]

89. Mok, J.S.; Song, K.C.; Lee, K.J.; Kim, J.H. Variation and profile of paralytic shellfish poisoning toxins in Jinhae bay, Korea. Fish Aquat. Sci. 2013, 16, 137-142. [CrossRef] 